\title{
Changes to the near-surface waters in the Canada Basin, Arctic Ocean from 1993-2009: A basin in transition
}

\author{
J. M. Jackson, ${ }^{1,2}$ S. E. Allen, ${ }^{1}$ F. A. McLaughlin, ${ }^{3}$ R. A. Woodgate, ${ }^{4}$ and E. C. Carmack ${ }^{3}$ \\ Received 21 February 2011; revised 13 July 2011; accepted 20 July 2011; published 12 October 2011.
}

[1] Increased sea ice melt and decreased surface albedo have changed the near-surface water mass structure of the Canada Basin. From 1993-2009, the near-surface temperature maximum (NSTM) and remnant of the previous winter's mixed layer (rWML) warmed by about $1.5^{\circ} \mathrm{C}$ and $0.5^{\circ} \mathrm{C}$ and freshened by about 4 and 2 practical salinity units, respectively. Results from a 1-D model suggest rWML warming can be explained by heat diffusion from both the NSTM and Pacific Summer Water (PSW). The same model predicts salinization of the rWML, whereas freshening was observed. This suggests that changes to the rWML are from both diffusion and the accumulation of freshwater. The rWML's salinity was associated with distance from the center of the Beaufort Gyre; the rWML at stations inside the gyre was on average 1.9 salinity units fresher than at stations outside. In addition, the salinity of PSW in the Canada Basin - defined by its local temperature maximum - freshened from about 30-32 in 1993 to 28-32 in 2008. Order of magnitude calculations suggest that neither changes in PSW source waters nor changes in advection pathways of PSW explain this freshening. Our model suggests that salt diffused from PSW to the freshening rWML; this diffusion increased (and freshened the PSW salinity range) as the rWML freshened. These results show that surface effects through warming and ice melt are felt to at least the depth of PSW. Observations from 2009 show the appearance of a third temperature maximum from an as yet unknown source.

Citation: Jackson, J. M., S. E. Allen, F. A. McLaughlin, R. A. Woodgate, and E. C. Carmack (2011), Changes to the nearsurface waters in the Canada Basin, Arctic Ocean from 1993-2009: A basin in transition, J. Geophys. Res., 116, C10008, doi:10.1029/2011JC007069.

\section{Introduction}

[2] The near-surface (here defined as the upper $\sim 100 \mathrm{~m}$ ) waters of the Canada Basin, Arctic Ocean (Figure 1) have warmed and freshened in recent years. The warming is related to the increased annual absorption of solar radiation [Perovich et al., 2007] due to the rapid decrease of summer sea ice [e.g., Steele et al., 2010]. The freshening is from both increased river runoff and sea-ice melt [Yamamoto-Kawai et al., 2009]. The increased accumulation of freshwater (herein the term freshwater includes both riverine and sea ice sources) has led to higher stratification and a shallower winter mixed layer [Toole et al., 2010] and the storage of summer solar radiation throughout winter [Jackson et al., 2010a].

[3] Increased sea ice melt and greater absorption of solar radiation have affected the near-surface water mass struc-

\footnotetext{
${ }^{1}$ Department of Earth and Ocean Sciences, University of British Columbia, Vancouver, British Columbia, Canada.

${ }^{2}$ Now at Department of Oceanography, University of Cape Town, Cape Town, South Africa.

${ }^{3}$ Fisheries and Oceans Canada, Institute of Ocean Sciences, Sidney, British Columbia, Canada.

${ }^{4}$ Applied Physics Laboratory, University of Washington, Seattle, Washington, USA.

Copyright 2011 by the American Geophysical Union. 0148-0227/11/2011JC007069
}

ture. In the Canada Basin, water masses have typically been defined as follows (Figure 2, 1993 curve). At the surface is a seasonal mixed layer whose depth was estimated as $40-50 \mathrm{~m}$ from the 1890s to 1970s [Coachman and Barnes, 1961; Morison and Smith, 1981] and 30-50 m in the 1990s [McLaughlin et al., 2004]. Year-round Ice-Tethered Profile (ITP) data collected from 2004-2008 showed that the surface mixed layer (defined as the first depth where the density difference relative to the density at $8 \mathrm{~m}$ was greater than $0.01 \mathrm{~kg} \mathrm{~m}^{-3}$ ) shoaled to an average depth of $16 \mathrm{~m}$ in summer and $24 \mathrm{~m}$ in winter [Toole et al., 2010].The base of the summertime surface mixed layer is called the summer halocline and it is formed when sea ice melt dilutes the surface mixed layer [Jackson et al., 2010a]. Below the summer halocline is a feature called the near-surface temperature maximum (NSTM). This NSTM is formed each summer by solar radiation that is trapped by the summer halocline [Jackson et al., 2010a]. During winter, the NSTM will either disappear if the summer halocline is eroded by winter mixing (that is primarily from haline convection), or it is trapped year-round below the summer halocline if winter mixing is constrained. The temperature minimum below the NSTM is thought to be the remnant of the previous winter's local mixed layer (rWML) [Jackson et al., 2010a]. The temperature of the rWML should be near freezing because the high arctic winter vertical mixing is dominated by surface 


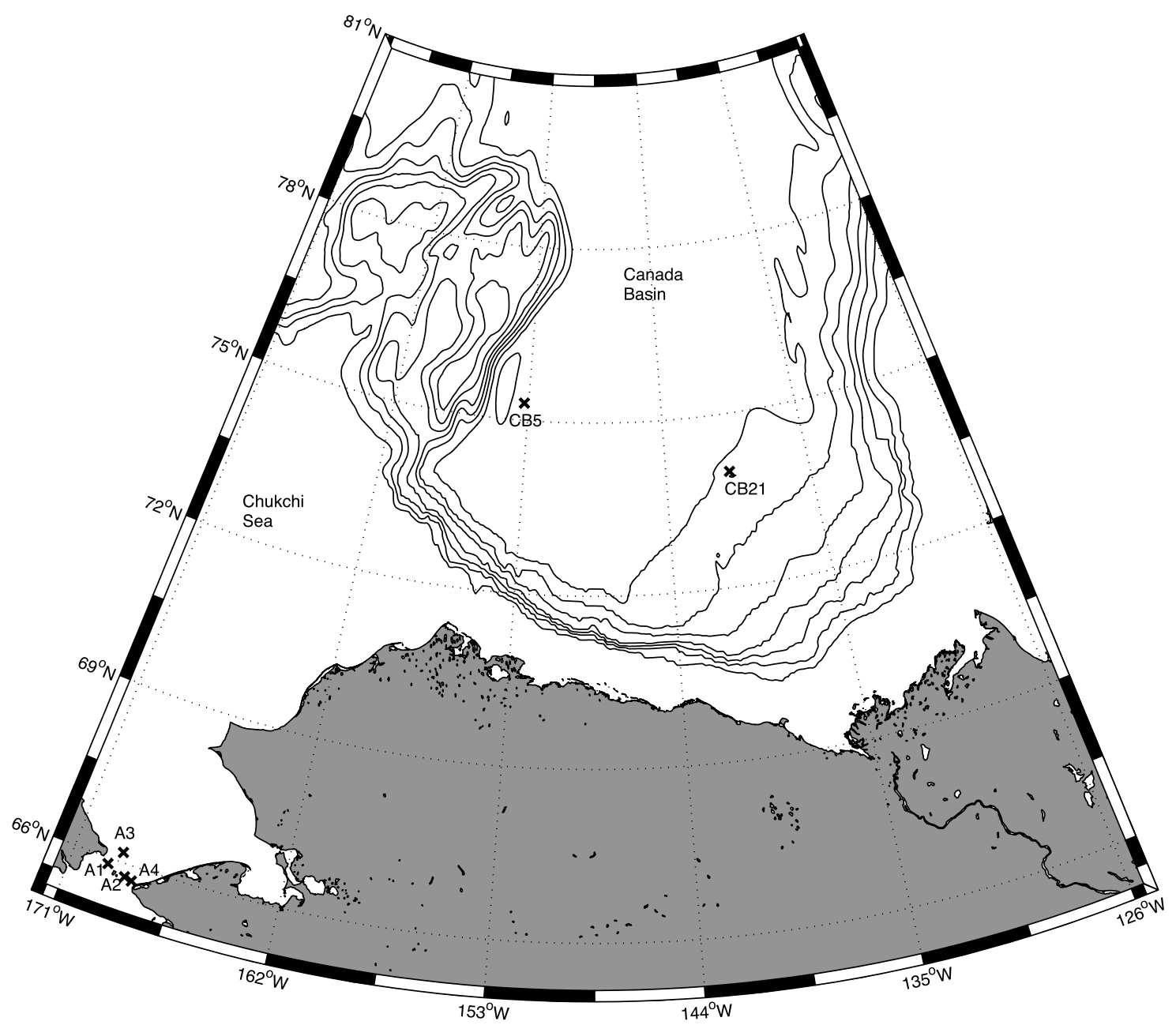

Figure 1. A bathymetric map of the Canada Basin and its surrounding shelves. The black contour lines estimate the bathymetry in $500 \mathrm{~m}$ intervals from $500 \mathrm{~m}$ to $3500 \mathrm{~m}$. The black $\mathrm{x}$ marks the station (CB5 and $\mathrm{CB} 21)$ and mooring (A1, A2, A3, and A4) locations.

freezing and haline convection rather than wind-forced mixing [Rudels et al., 1996]. The temperature maximum below the rWML has long been defined as water of Pacific origin that is modified during summer [Coachman and Barnes, 1961] and here we call this second temperature maximum Pacific Summer Water (PSW). PSW is thought to be modified in the eastern Chukchi Sea and has also been called eastern Chukchi Sea water (ECSW) by Shimada et al. [2001]. Steele et al. [2004] identified two types of PSW - a warmer, fresher (salinity range 31 to 32 ) type that they call Alaskan Coastal Water (ACW) and a colder saltier (salinity range 32 to 33 ) type that they call summer Bering Sea Water. ACW is usually found in the southern and central Canada Basin while summer Bering Sea Water is found in the northern Canada Basin [Steele et al., 2004], thus in this paper we focus on the ACW-type water that we simply call PSW. A major component of ACW is carried by a warm, fresh seasonal coastal current called the Alaskan Coastal Current (ACC) [Steele et al., 2004; Woodgate and Aagaard, 2005]. A second halocline separates the rWML and PSW and we call this the winter halocline because it is the base of the surface mixed layer in winter. Finally, the temperature minimum below PSW is Pacific Winter Water (PWW) and its source is
Pacific water that is modified in the Chukchi and Bering Seas during winter [Coachman and Barnes, 1961].

[4] The warming and freshening of the near-surface waters described above is affecting the ecology of the Canada Basin. Recent studies have shown the deepening of the subsurface chlorophyll maximum by an average depth of $45 \mathrm{~m}$ in 2003 to $61 \mathrm{~m}$ in 2008 [Jackson et al., 2010b], the deepening of the nutricline [McLaughlin and Carmack, 2010], and a transition in food web structure with decreasing abundance of nanoplankton (2-20 $\mu \mathrm{m}$ diameter) and increasing abundance of picoplankton ( $<2 \mu \mathrm{m}$ diameter) [ $L i$ et al., 2009]. The rWML is observed at a similar depth range as the chlorophyll maximum. Thus, changes to properties of the rWML could alter primary production. In addition, phytoplankton rely on nutrients that are transported into the Canada Basin within modified Pacific waters [Carmack et al., 2004], and so changes to these Pacific waters would be expected to impact primary production.

[5] In this paper, we use summer CTD data to examine changes to the near-surface $(0-100 \mathrm{~m})$ water masses in the Canada Basin from 1993-2009. Section 2 discusses details of the data and of the 1-D model used to estimate vertical heat diffusion. The data show warming and freshening of 

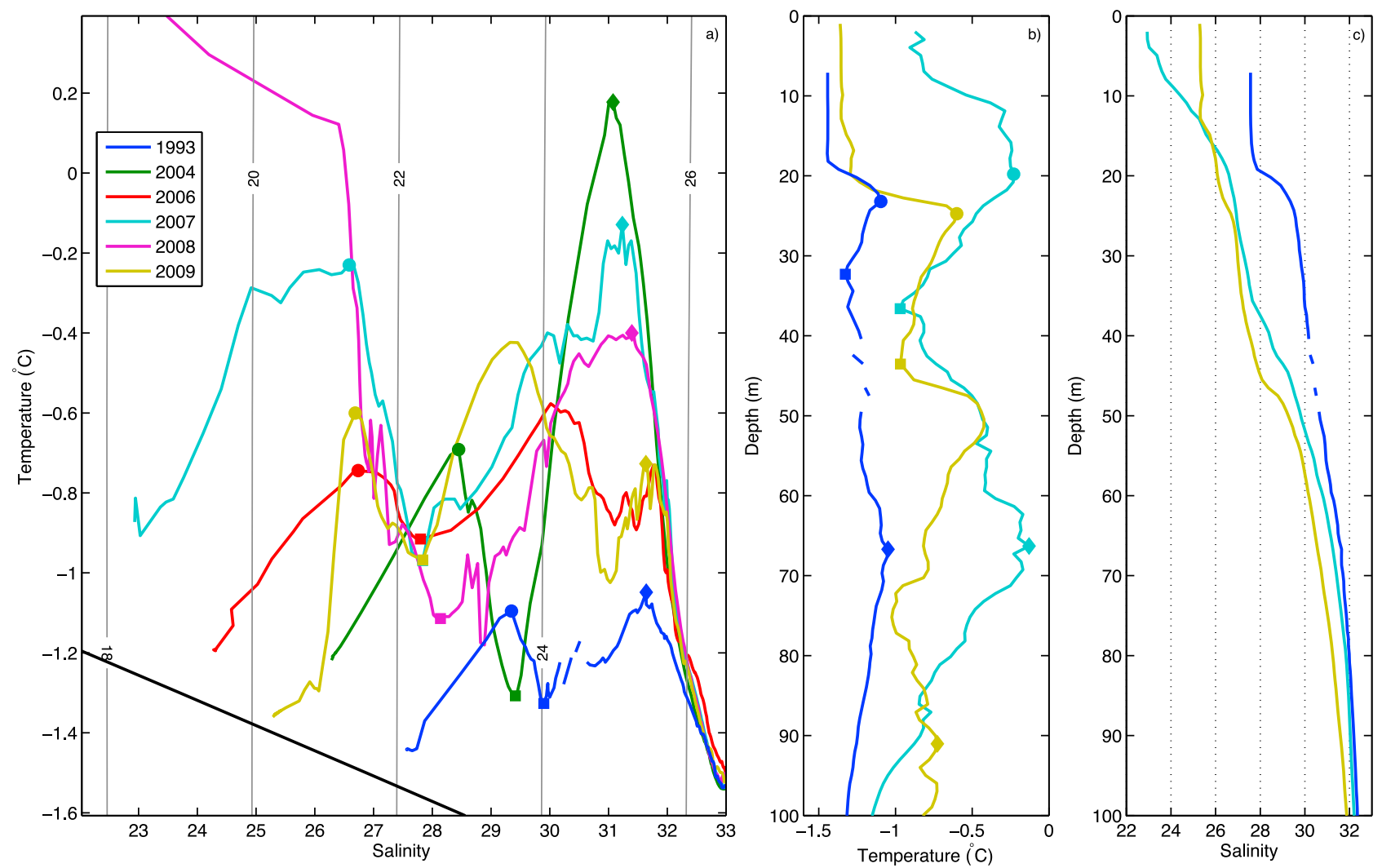

Figure 2. A comparison of temperature and salinity above Atlantic water at station $\mathrm{CB} 21\left(74^{\circ} \mathrm{N}, 140^{\circ} \mathrm{W}\right)$. Here we show (a) temperature-salinity plots, (b) profiles of temperature, and (c) profiles of salinity. Samples were taken on 11 September, 1993 (blue line), 24 August, 2004 (green line), 8 September, 2006 (red line), 23 August, 2007 (cyan line), 14 August, 2008 (purple line), and 9 October, 2009 (mustard line). The colored symbols mark the temperature maximum near-surface temperature maximum (NSTM; circle), the temperature minimum remnant of the previous winter layer (rWML; square) and temperature maximum that is likely Pacific summer water (PSW; diamond) for each year. PSW is not indicated in 2006 because it appears as though cold water intruded on the temperature maximum. While this appears to be similar in 2009, an examination of other stations found that three temperature maxima were ubiquitous in 2009 and an anomaly in 2006. The black solid line represents the freezing temperature as a function of salinity and pressure and the grey lines denote density (sigma-theta) at 2 unit intervals.

the NSTM and rWML and the apparent freshening of PSW. The warming of the NSTM is discussed by Jackson et al. [2010a]. In section 3, we examine changes to the rWML. In section 4, we investigate the role of the Beaufort Gyre in determining water mass distribution and properties. In section 5 , we examine three different mechanisms that could cause PSW to freshen - viz., changes to the source waters of PSW, changes to the advective pathway and velocity of PSW, and changes to the vertical diffusion of heat and salt in the upper $100 \mathrm{~m}$. These mechanisms are examined in isolation but all could be acting together.

\section{Data and Methods}

\subsection{Definition of the Near-Surface Water Masses}

[6] Following Jackson et al. [2010a], we define the NSTM as being present if (1) the temperature maximum that is nearest to the surface is at least $0.1^{\circ} \mathrm{C}$ warmer than the temperature minimum directly below (e.g., the rWML);
(2) the salinity of this temperature maximum is less than 31 (throughout this paper, salinity is reported as salinity units that are based on the Practical Salinity Scale [United Nations Educational and Scientific Cultural Organization, 1981]); and (3) the temperature maximum is at least $0.2^{\circ} \mathrm{C}$ warmer than the freezing temperature.

[7] We then define the rWML as the temperature minimum directly below the NSTM that exists if it is at least $0.1^{\circ} \mathrm{C}$ colder than the NSTM. Thus, by this definition, the NSTM cannot exist without the rWML and vice-versa. If there appear to be multiple temperature maxima and minima that fit these criteria (e.g., the 2009 profile in Figure 2) then the NSTM is the temperature maximum nearest the surface and the rWML is the temperature minimum directly below the NSTM.

[8] The PSW is defined as the temperature maximum directly below the rWML that is at least $0.1^{\circ} \mathrm{C}$ warmer than the rWML. If only one temperature maximum was present above $100 \mathrm{~m}$, the NSTM was distinguished from PSW using 
Table 1. Cruise Dates for CTD Data Collection

\begin{tabular}{cc}
\hline Year & Date Range \\
\hline 1993 & Aug 3-Sep 25 \\
2002 & Aug 18-Sep 5 \\
2003 & Aug 13-Sep 3 \\
2004 & Aug 5-30 \\
2005 & Aug 3-31 \\
2006 & Aug 7-Sep 12 \\
2007 & Jul 27-Aug 28 \\
2008 & Jul 23-Aug 20 \\
2009 & Sep 20-Oct 12 \\
\hline
\end{tabular}

salinity - a temperature maximum whose salinity was less than 31 was an NSTM and greater than 31 was PSW. These definitions were applicable to all data considered here, except for the 2009 data, where three near-surface temperature maxima were observed. So in 2009 we chose to define PSW as the only temperature maximum with a salinity greater than 31 and this definition of PSW will be examined further in section 5 .

\subsection{CTD Data}

[9] We use CTD data collected by a collaboration of researchers from Fisheries and Oceans Canada (DFO), the Japan Agency for Marine-Earth Science and Technology, and the Woods Hole Oceanographic Institution from 20022009 using a SeaBird SBE-911 Plus CTD (details given by McLaughlin et al. [2008]) and data collected by DFO researchers in 1993 using a FSI CTD ICTD [Macdonald et al., 1995]. Cruises took place in late summer and we note that the 2009 cruise started 1-2 months later than the previous cruises (Table 1).

\subsection{Ice-Tethered Profiler Data}

[10] We also use year-round archived (level 3) CTD data from the ITP (http://www.whoi.edu/itp) [Toole et al., 2006; Krishfield et al., 2008] instrument number 8, which collected daily data from 12 August, 2007 - 24 July, 2008 in the northern Canada Basin. Uncertainties in the CTD data are estimated at 0.005 salinity units and $0.005^{\circ} \mathrm{C}[$ Krishfield et al., 2008]. Data collection commences at about $8 \mathrm{~m}$ and continues to $800 \mathrm{~m}$ with $1 \mathrm{~m}$ resolution. We note that these data are biased to waters that have a high ambient ice concentration. Profiles from every third day were examined and those that started deeper than $10 \mathrm{~m}$ were ignored.

\subsection{Bering Strait Mooring Data}

[11] We also use time-series temperature and salinity data from the Bering Strait from 2001-2009 [Woodgate et al., 2010 and references therein] (see also http://psc.apl. washington.edu/BeringStrait.html). Year-round moorings with fixed depth sensors have been deployed in the 2 channels of the strait and at a site just to the north almost continuously since 1990 (not all moorings were deployed all years; Figure 1). We use data from moorings in the eastern strait (site A2- center of the strait, sampling mostly ACW, and site A4 - nearer to the United States coast, sampling mostly in the ACC) and from the northern site (A3), believed to be a useful average of the total flow through the strait [Woodgate et al., 2005b]. The time series are from about $9 \mathrm{~m}$ above the seafloor thus do not measure the upper waters, which in summer and fall are likely up to $2^{\circ} \mathrm{C}$ warmer and 1 salinity unit fresher [Woodgate et al., 2005a, 2005b].

\subsection{Sea Ice Data}

[12] Sea ice concentrations were obtained from the National Snow and Ice Data Center (http://www.nsidc.org). We used the August averaged $25 \mathrm{~km}$ final data produced from the Nimbus-7 Scanning Multichannel Microwave Radiometer (SMMR) and the Defence Meteorological Satellite Program (DMSP) -F8, -F11 and -F13 Special Sensor Microwave/Imager (SSM/I) radiances [Cavalieri et al., 1996] for the years 1993 and 2002-07. Since -F13 was lost at the end of 2007, for 2008 and 2009 we used the nearreal-time $25 \mathrm{~km}$ DMSP SSM/I daily polar gridded sea ice concentrations [Maslanik and Stroeve, 1999] from the -F17 satellite. We used sea ice concentrations from the middle of the cruise - August 5, 2008 and October 1, 2009 - to estimate the sea ice conditions since monthly averages are not available.

\subsection{Model of Heat and Salt Diffusion}

[13] In section 5, we use a 1-D vertical diffusion model to study changes in temperature and salinity in the upper $100 \mathrm{~m}$ of the Canada Basin. Although vertical diffusion coefficients are generally considered to be small in the Arctic [Rudels et al., 1996; Gargett, 2003], the large temperature and salinity gradients in the near-surface waters suggest the effects of diffusion may be significant. By central derivative finite difference, we solve

$$
\frac{\partial T}{\partial t}=\kappa \frac{\partial^{2} T}{\partial z^{2}}, \quad \frac{\partial S}{\partial t}=\kappa \frac{\partial^{2} S}{\partial z^{2}}
$$

where $\mathrm{t}$ is time, $\mathrm{T}$ is temperature, $\mathrm{S}$ is salinity, $\mathrm{z}$ is depth and $\kappa$ is the vertical diffusivity (from both molecular and turbulent processes) for temperature or salinity. As previous studies found $\kappa$ values of $1-3 \times 10^{-6} \mathrm{~m}^{2} \mathrm{~s}^{-1}$ in the polar ocean below the mixed layer [Rudels et al., 1996; Gargett, 2003], two separate model experiments were run, one with a diffusivity of $1 \times 10^{-6} \mathrm{~m}^{2} \mathrm{~s}^{-1}$ and the other with a diffusivity $3 \times 10^{-6} \mathrm{~m}^{2}$ $s^{-1}$. Here, depth-independent $\kappa$ is a first approximation of diffusivity. Real diffusivities are not expected to be constant through the water column, however tests using variation of $\kappa$ as 1/N [Denman and Gargett, 1995], where $\mathrm{N}$ is the Brunt-Väisälä frequency, did not qualitatively change the results. This simple model does not include solar heating or other surface processes, advection, horizontal variability, or mixing driven by brine-rejection from sea-ice on freezing. A different model is needed to examine the other processes.

[14] The model was run for the upper $100 \mathrm{~m}$ for summer profiles from two different stations - CB5 $\left(75.3^{\circ} \mathrm{N}, 153.3^{\circ} \mathrm{W}\right.$; Figure 1) near the southern Northwind Ridge and CB21 $\left(74^{\circ} \mathrm{N}, 140^{\circ} \mathrm{W}\right.$; Figure 1$)$ in the center of the basin. Zero flux of heat and salt were used at the upper and lower boundaries; these were set to the temperature or salinity that was one space step away (above or below) from the boundary. Salt and temperature were diffused separately but no profiles developed density instability because the density variation is so dominated by salinity. The model used a vertical resolution of $0.25 \mathrm{~m}$ and a time step of 50 minutes, both of which were sufficiently small that the solution was independent of 


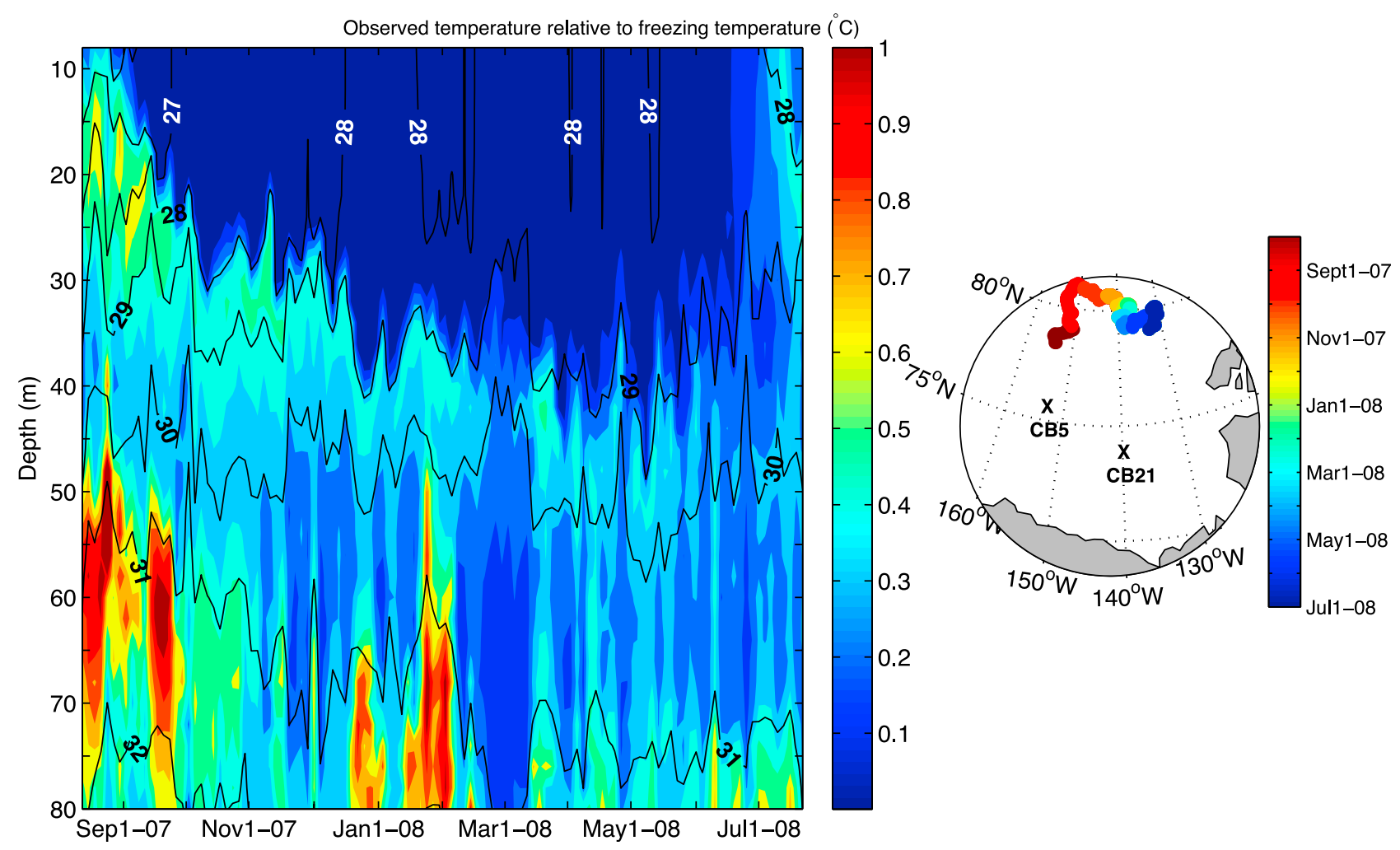

Figure 3. (left) Observations from ITP8, where data were collected from 12 August, 2007 - 24 July, 2008. The color is the observed temperature relative to the freezing temperature. The black lines indicate salinity contours. The location of ITP8 over time. (right) Stations CB5 $\left(75.3^{\circ} \mathrm{N}, 153.3^{\circ} \mathrm{W}\right)$ and CB21 $\left(74^{\circ} \mathrm{N}, 140^{\circ} \mathrm{W}\right)$ are denoted by a black $x$.

resolution. The model was run for 1 year to estimate conditions during the following year's cruise.

\section{Results: Changes to the Near-Surface Water Masses, 1993-2009}

\subsection{The NSTM and rWML}

[15] The CTD data showed clear changes to the nearsurface properties from 1993 through 2009, e.g., at station CB21 in the central Canada Basin (Figure 2). Since 2004, the depth of the winter mixed layer has shoaled in the central Canada Basin due to increased freshening and near-surface stratification [Toole et al., 2010; McLaughlin and Carmack, 2010], which has resulted in the year-round survival of the NSTM [Jackson et al., 2010a]. Since successive stronglystratified NSTMs are formed at progressively fresher salinities (Figure 2) that may then descend by gyre-driven downwelling, we would expect to identify annual NSTM layers stacked one on top of each other. If sufficiently deep, these layers may be isolated from surface mixing during winter. Toole et al. [2010] found that the average winter mixed layer depth from the summer 2004 through the summer 2009 was $24 \mathrm{~m}$ and Jackson et al. [2010a] showed, based on all available ITP data, that almost without exception, the NSTM was consistently deeper than $30 \mathrm{~m}$ in winter. Data from ITP8 show how the new NSTM that appeared in July 2008 formed above the NSTM from the summer of 2007 (Figure 3). This was the first time that the NSTM was observed year-round [Jackson et al., 2010a] and the NSTM that formed during the summer of 2008 (at salinity 28) was at least 1 salinity unit fresher than the 2007 NSTM (at salinity 29). Thus, unless there was sufficient diffusive mixing below the 2008 summer halocline, the 2007 NSTM should form a separate and denser layer below the lighter 2008 NSTM. With the exception of 2009, separate and stacked NSTM and rWML layers were not evident and instead both the NSTM and rWML warmed and freshened together through each summer (Figure 2). It is only in 2009 that two temperature maxima and two temperature minima were successively stacked and multiple NSTM and rWML-like sequences were observed.

[16] From 1993 to 2009, the NSTM and the rWML warmed by about $1.5^{\circ} \mathrm{C}$ and $0.5^{\circ} \mathrm{C}$, respectively (Figure 2). To determine the spatial extent of the warming, the summer temperature (Figure 4) at the rWML was plotted with the summer sea ice concentration. To minimize confusion from shelf and shelf-exchange effects, only stations whose bottom depth was greater than $3000 \mathrm{~m}$ were examined. Similar to the NSTM, the rWML warmed during our study period and it appeared in general that the warmer rWMLs were in regions with reduced sea ice. The exception was 2009, where warm rWMLs were observed under relatively high sea ice concentrations. We attribute this exception to the later sampling in 2009, which occurred during sea ice formation. This warming is at first puzzling because the temperature of the rWML should be independent of sea ice concentration since it is formed in winter when the surface mixed layer is at the 

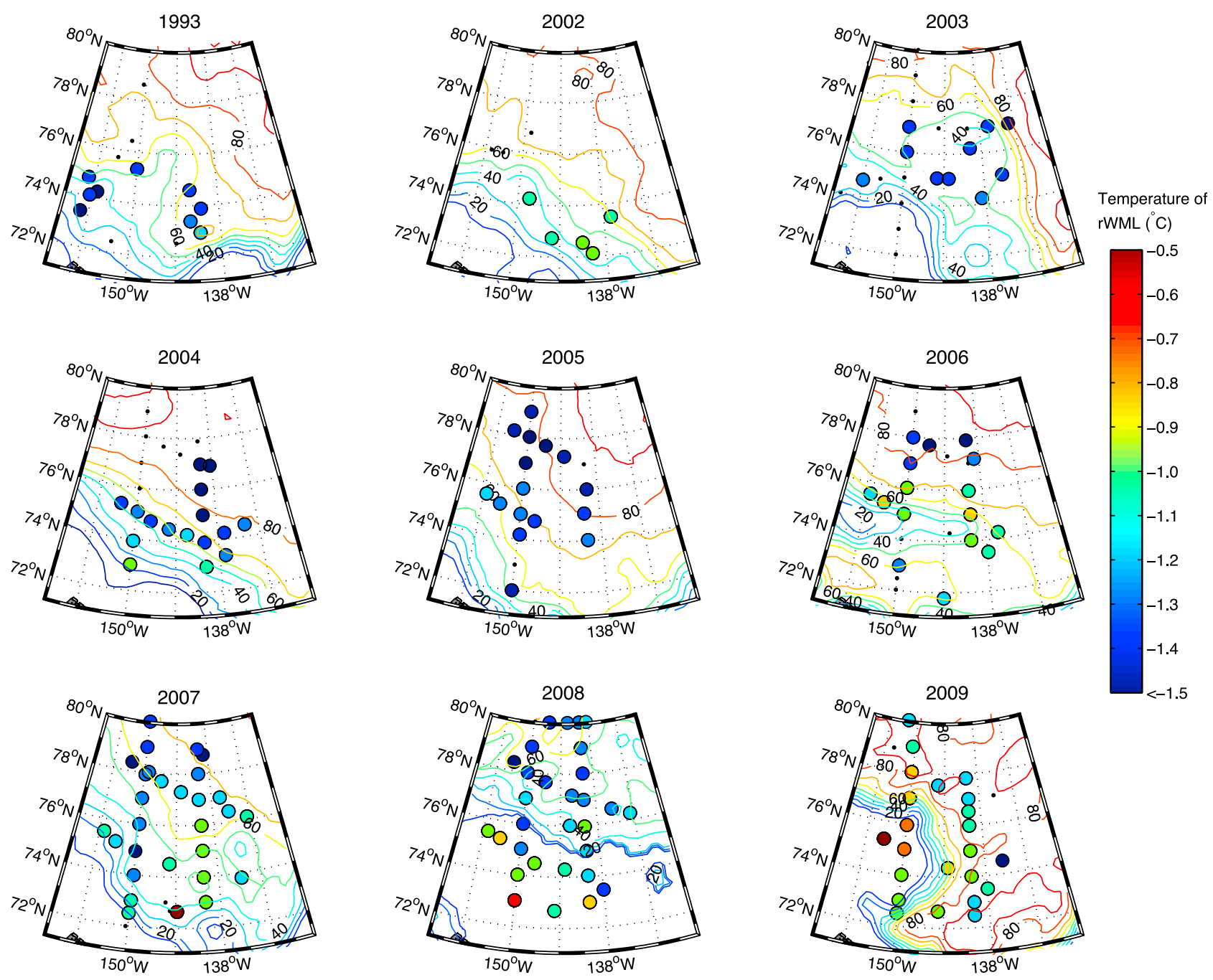

Figure 4. The temperature at the rWML during the summer cruises of 1993 and 2002-2009. To minimize confusion from coastal processes, only stations whose bottom depth was greater than $3000 \mathrm{~m}$ were plotted. Black dots represent stations where no rWML was present. Contour lines estimate the monthly averaged sea ice concentration at $10 \%$ intervals during each cruise.

freezing temperature. Modifications to the temperature of the rWML will be examined in section 5.3.

[17] From 1993 through 2009, the NSTM and rWML freshened by about 4 and 2 salinity units, respectively. The spatial extent of the freshening was also plotted with the summer sea ice concentration (Figure 5). The salinity trend seemed to be more variable and less linked to ice conditions, with the freshest rWMLs observed in 2002-2003 and 20062009. The freshest rWMLs appeared to be clustered at a slightly different location each summer, suggesting that the salinity of the rWML may be influenced by the location of the Beaufort Gyre. The relationship between the salinity of the rWML and the location of the Beaufort Gyre will be examined in section 3.2.

[18] From 2004-2008, the PSW temperature maximum was about 2 salinity units fresher (at salinity 28-32) than the salinity of 31.6-32.4 defined by Coachman and Barnes [1961] and the salinity of 31-32 defined by Shimada et al. [2001] for eastern Chukchi Sea water and Steele et al. [2004] for ACW.
[19] In 2009, two temperature maxima were observed below the NSTM. The source of the middle temperature maximum is unknown. It could be advection of warmer and fresher PSW or another water mass (e.g., shelf water as was discussed by Shimada et al. [2001]) that formed between the rWML and PSW. Changes to PSW will be explored in Section 5.

\subsection{The Location of Center the Beaufort Gyre}

[20] Several recent papers have identified decreasing salinities within the Beaufort Gyre [e.g., Proshutinsky et al., 2009; McPhee et al., 2009; Jahn et al., 2010], so it is possible that the salinity of the rWML is affected by the location of this gyre. In the northern hemisphere, anticyclonic (convergent) gyres have a bowl shape, with isohalines deeper in the center and shallower at the edge; thus, the location of the Beaufort Gyre can be identified by plotting the depths of isohalines. We observed that the isohalines deepened during our study period (discussed further in section 4), thus the same isohalines could not be examined each year for com- 

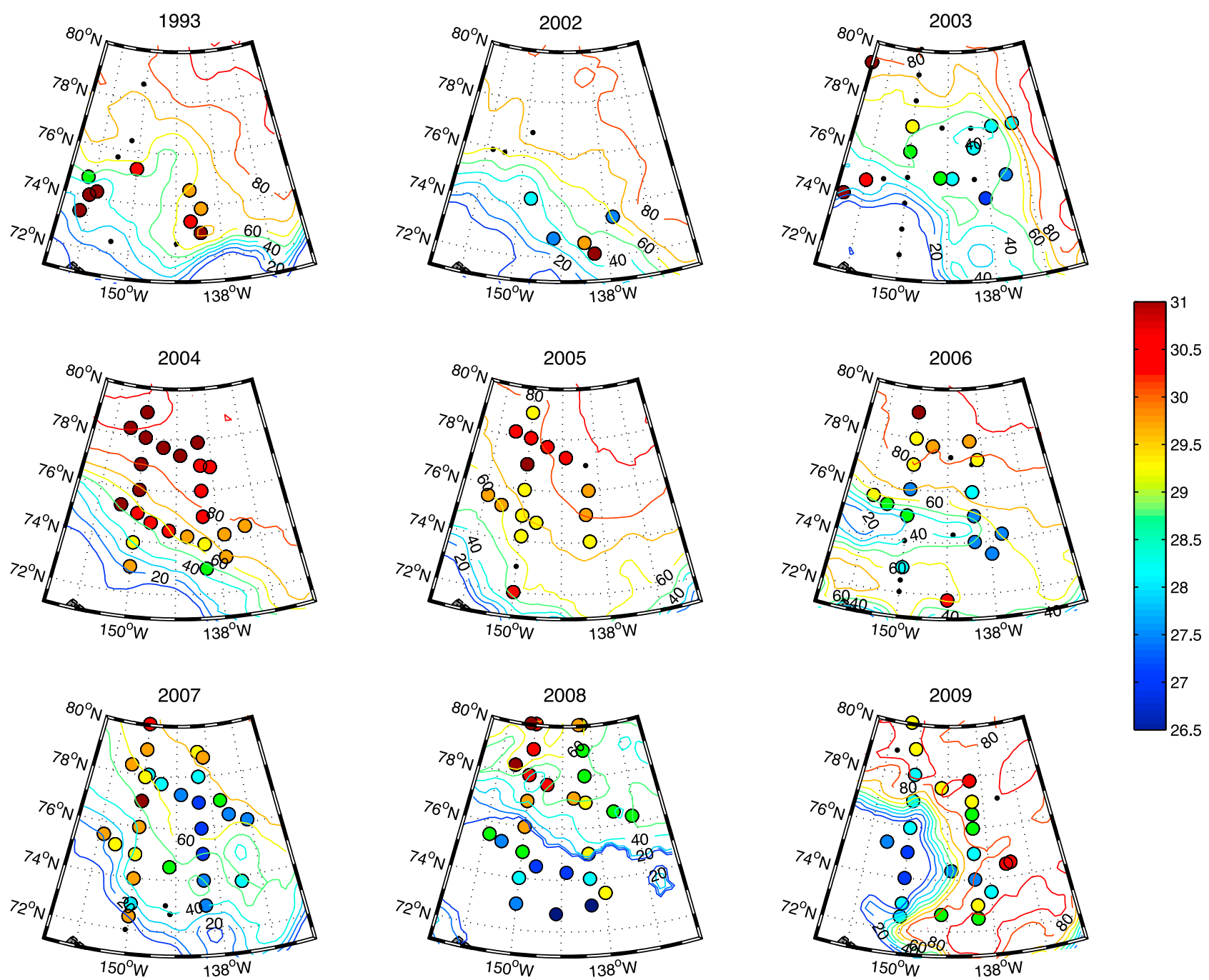

Figure 5. As in Figure 4 but for the salinity at each rWML.

parative purposes. Initially, we observed (based on contoured isopycnals across the Canada Basin - not shown) that the depth of the base of the Beaufort Gyre (the deepest part of the bowl shape) was usually less than $50 \mathrm{~m}$. We consider here the isohaline that was at $40 \mathrm{~m}$ (Table 2) in the center of the gyre (Figure 6); however results were not sensitive to this depth choice. By plotting depths of the chosen isohaline, we find that the location of the Beaufort Gyre was variable and appeared to be in the southeast Canada Basin in 2002 and 2004-2006, in the central Canada Basin in 1993, 2007, and 2008, in the northeast Canada Basin in 2003, and in the southwest Canada Basin in 2009.

[21] Unsurprisingly, given the bowl shape of the gyre, the salinity of the rWML was negatively correlated with the local depth of the chosen isohaline, suggesting the rWML was fresher inside the Beaufort Gyre. To elucidate this relationship, the average salinity of the rWML was calculated for three different regions - i.) The inside of the Beaufort Gyre, which was defined as the region where the depth of the chosen isohaline was $25-40 \mathrm{~m}$; ii.) The outside of the Beaufort Gyre, which was the region where the depth of the chosen isohaline was $0-15 \mathrm{~m}$; and iii.) The transition zone between the inside and outside of the gyre, which was defined as the region where the depth of the chosen isohaline was 16-24 m (Figure 7). There were some instances when the depth of the chosen isohaline was inconsistent with the surrounding stations (e.g., the station at $76^{\circ} \mathrm{N}$, $140^{\circ} \mathrm{W}$ in 2005$)$. These anomalies could be caused by the

Table 2. The Salinity at $40 \mathrm{~m}$ in the Center of the Beaufort Gyre and the Number of Stations That Were Defined as Inside the Gyre, Outside the Gyre, and in the Transition Zone From 1993-2009

\begin{tabular}{ccccc}
\hline Year & $\begin{array}{c}\text { Salinity } \\
\text { at } 40 \mathrm{~m}\end{array}$ & $\begin{array}{c}\text { Inside } \\
\text { the Gyre }\end{array}$ & $\begin{array}{c}\text { Outside } \\
\text { the Gyre }\end{array}$ & $\begin{array}{c}\text { In Transition } \\
\text { Zone }\end{array}$ \\
\hline 1993 & 30 & 4 & 0 & 13 \\
2002 & 29.5 & 5 & 0 & 2 \\
2003 & 29.5 & 19 & 1 & 1 \\
2004 & 29 & 7 & 8 & 8 \\
2005 & 29 & 9 & 2 & 6 \\
2006 & 28.5 & 13 & 2 & 10 \\
2007 & 27.5 & 9 & 9 & 14 \\
2008 & 27 & 6 & 11 & 8 \\
2009 & 27.5 & 13 & 5 & \\
\hline
\end{tabular}



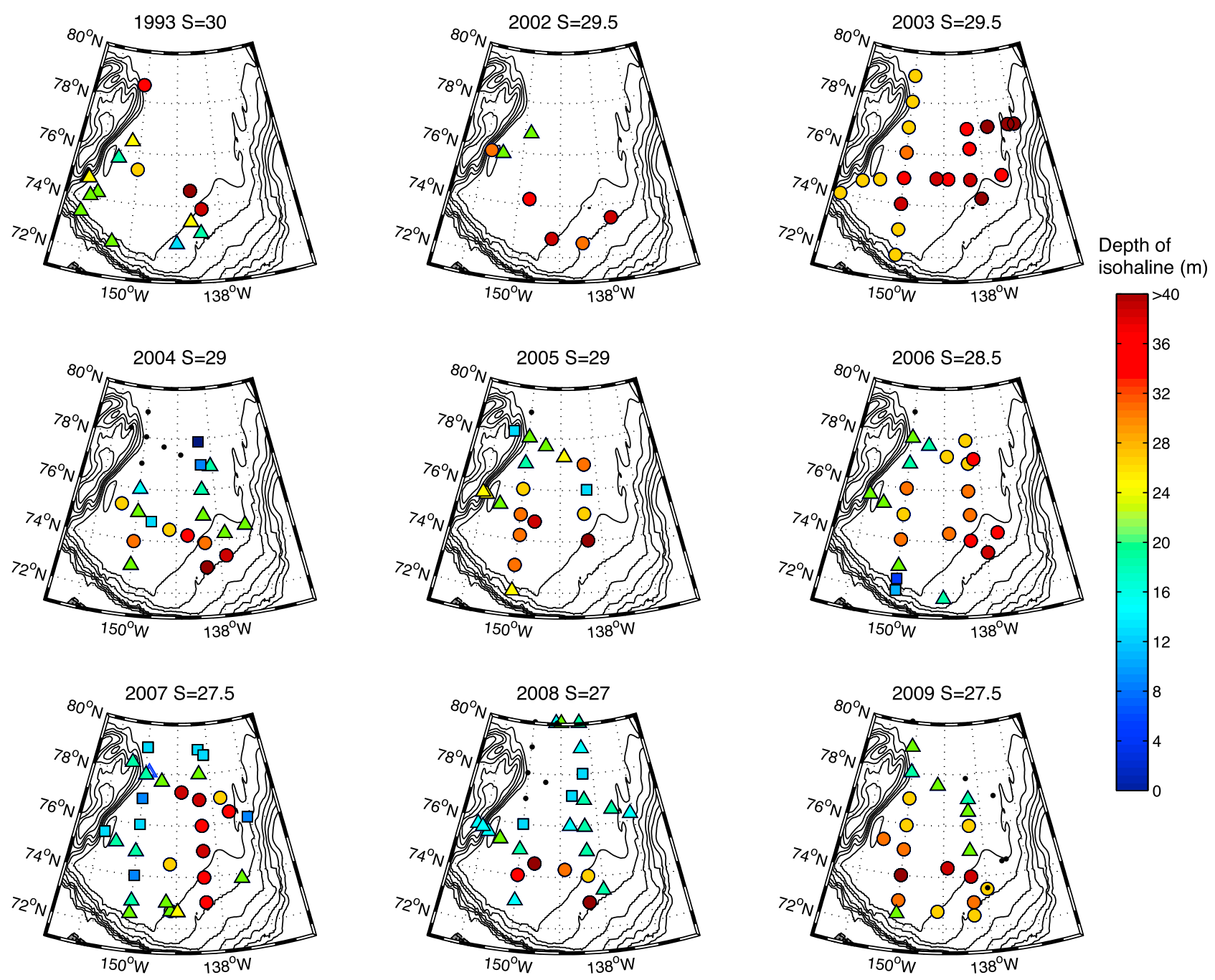

Figure 6. The depth of a chosen isohaline to outline the location of the Beaufort Gyre (details in text). This isohaline was 30 salinity units in 1993, 29.5 in 2002 and 2003, 29 in 2004 and 2005, 28.5 in 2006 , 27.5 in 2007 and 2009 and 27 in 2008 . Colored circles represent stations that were inside the Beaufort Gyre, triangles represent stations that were in the transition zone, squares represent stations that were outside of the gyre and black dots indicate stations that were sampled where the surface was saltier than the chosen isohaline (and thus outside of the gyre). Black lines show the bathymetry at $500 \mathrm{~m}$ intervals from $500 \mathrm{~m}$ to $3500 \mathrm{~m}$.

passage of internal waves [Pinkel, 2005; Rainville and Woodgate, 2009] or shallow water eddies [Timmermans et al., 2008] and both processes would cause the isohalines to heave. The inconsistent halocline depths occurred in 7 out of 195 stations and we chose to remove them from the following analyses. In addition, since the interior of the Canada Basin was sparsely sampled in 1993 and 2002, it is probable that the exact center of the Beaufort Gyre was not sampled. Thus, we chose to also exclude the years 1993 and 2002 from the following analyses.

[22] The rWML was on average 1.9 salinity units fresher inside than outside the gyre, with the greatest difference (3.0 salinity units) in 2008 and the smallest difference (1.1 salinity units) in 2004. Given these salinity differences, we suggest that the observed freshening of the rWML can be partially attributed to its location relative to the Beaufort Gyre. This is because the properties of the rWML should reflect the surface salinity where it was formed by haline convection; if formed in the center of the gyre, the rWML should be fresher than if it was formed outside the gyre. The effect of the Beaufort Gyre on near-surface water masses will be explored further in Section 4.

\section{Effect of the Beaufort Gyre on Changing Water Mass Properties}

[23] To examine how the Beaufort Gyre influences water mass properties, the average temperature and salinity profiles for stations inside the Beaufort Gyre, outside the Beaufort Gyre and within the transition zone during each summer cruise were calculated (Figure 8). These profiles confirm that from 2003-2008, the NSTM, rWML and PSW were coldest and saltiest outside of the gyre and warmest and freshest inside the gyre. In addition, PSW had a greater 


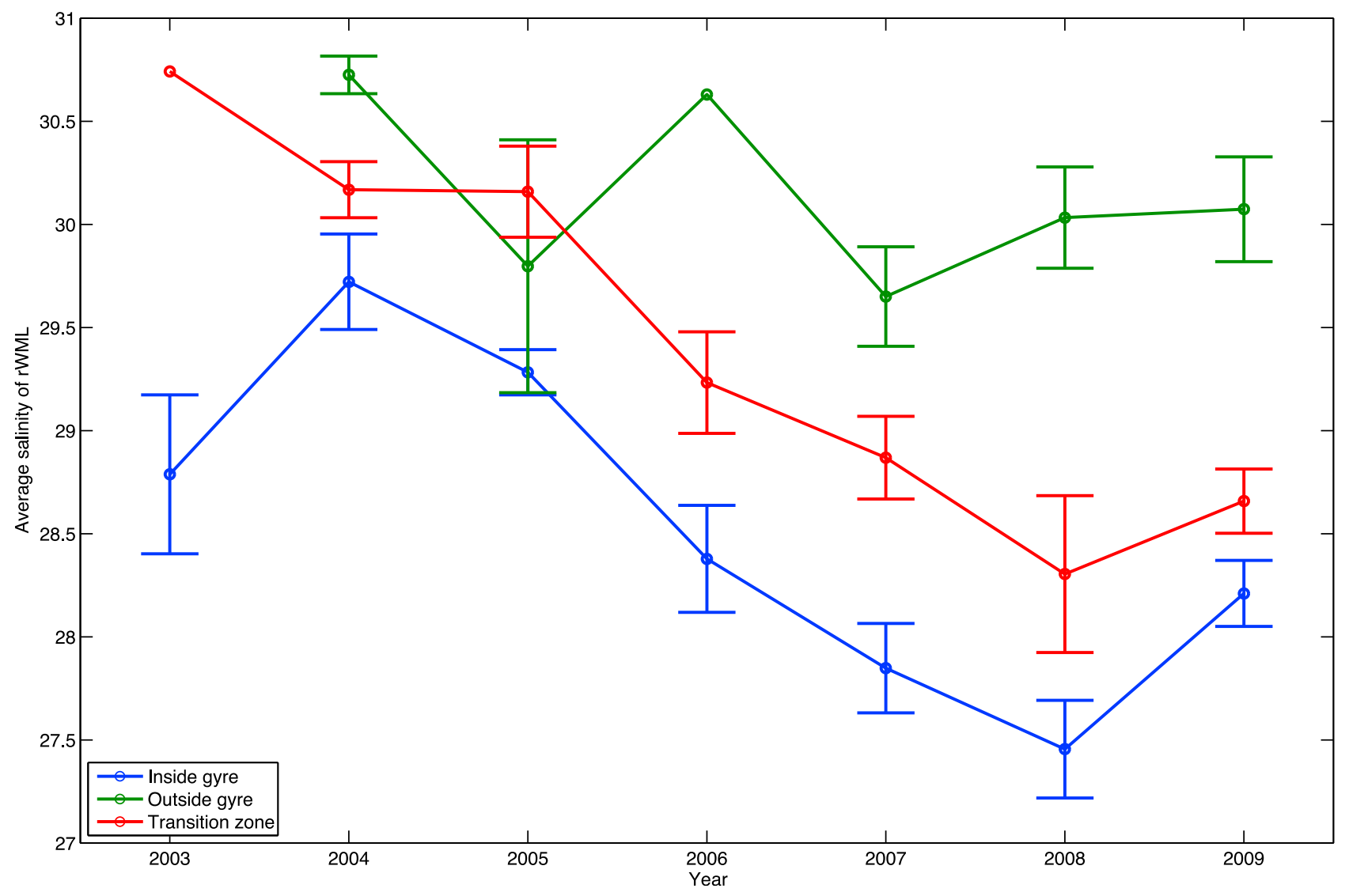

Figure 7. Average salinity (with standard error bars) of the rWML for stations that were within the Beaufort Gyre (blue line), outside of the Beaufort Gyre (green line) and in the transition zone between the center and edge of the Beaufort Gyre (red line). Stations inside of the Beaufort Gyre were those where the isohaline defined in Figure 5 (29.5 in 2003, 29 in 2004 and 2005, 28.5 in 2006, 27.5 in 2007 and 2009 and 27 in 2008) had a depth of 25-40 m. The depth of the isohaline outside of the gyre was up to $15 \mathrm{~m}$ while the depth of the isohaline in the transition zone was 16-24 m. The years 1993 and 2002 were not included because sparse sampling meant the location of the center of the Beaufort Gyre was uncertain. Only stations that had a bottom depth greater than $3000 \mathrm{~m}$ were used to calculate the average.

salinity range, from about $29.5-32$ in 2004 to $28-32$ in 2007, inside the gyre. Data from 2009, however, were strikingly different - inside the gyre there were three temperature maxima (at salinities 26.6, 29.5 and 31.5) and two temperature minima (at salinities 28.1 and 30.9), in the transition zone there were two temperature maxima (at salinities 28.1 and 30.5 ) and one temperature minimum (at salinity 28.7), and outside the gyre there was only one temperature maximum (at salinity 30.3 ) that extended over the salinity range of about 28-32. Thus, an extra temperature maximum was observed between the NSTM and PSW only inside the Beaufort Gyre.

[24] The chlorophyll $a$ maximum layer deepened in the Canada Basin between 2003-2008 [Jackson et al., 2010b; McLaughlin and Carmack, 2010] and this is linked to the deepening of the winter halocline and underlying nutrientrich Pacific waters [McLaughlin and Carmack, 2010]. To examine the spatial extent of this deepening, the average depths of the NSTM, rWML and PSW (relative to the location of the center of the Beaufort Gyre) were calculated.

[25] The NSTM ranged from about $1-35 \mathrm{~m}$ and did not appear to be influenced by the location of the Beaufort Gyre
(Figure 9a). The NSTM shoaled in all regions and this trend was linear (2.0 m per year from 2004-2008) and statistically significant ( $p$-value $=0.04$ for the 5 years) only in the transition zone from 2004-2008. The shoaling of the NSTM also caused it to thicken (Figure 2b). A deeper NSTM was observed throughout the basin in 2009 and this was likely caused by the later sampling date, which allowed more time for downwelling and winter deepening of the surface mixed layer.

[26] From 2003-2009, the average depth of the rWML ranged from about $25-55 \mathrm{~m}$ but was consistently $35-45 \mathrm{~m}$ from 2004-2009 when most of the southern Canada Basin was sampled (Figure 9b). Similar to the NSTM, the depth of the rWML did not appear to be influenced by the location of the Beaufort Gyre. In contrast to the NSTM, the rWML had no statistically significant shoaling trend ( $\mathrm{p}$-value from 2004-2009 ranged from 0.07 for stations in the transition zone to 0.52 for stations inside the gyre). No shoaling trend suggests that changes to the near-surface stratification in summer do not affect the depth of the rWML.

[27] Unlike the NSTM and rWML, the depth of PSW appeared to be influenced by the location of the Beaufort 

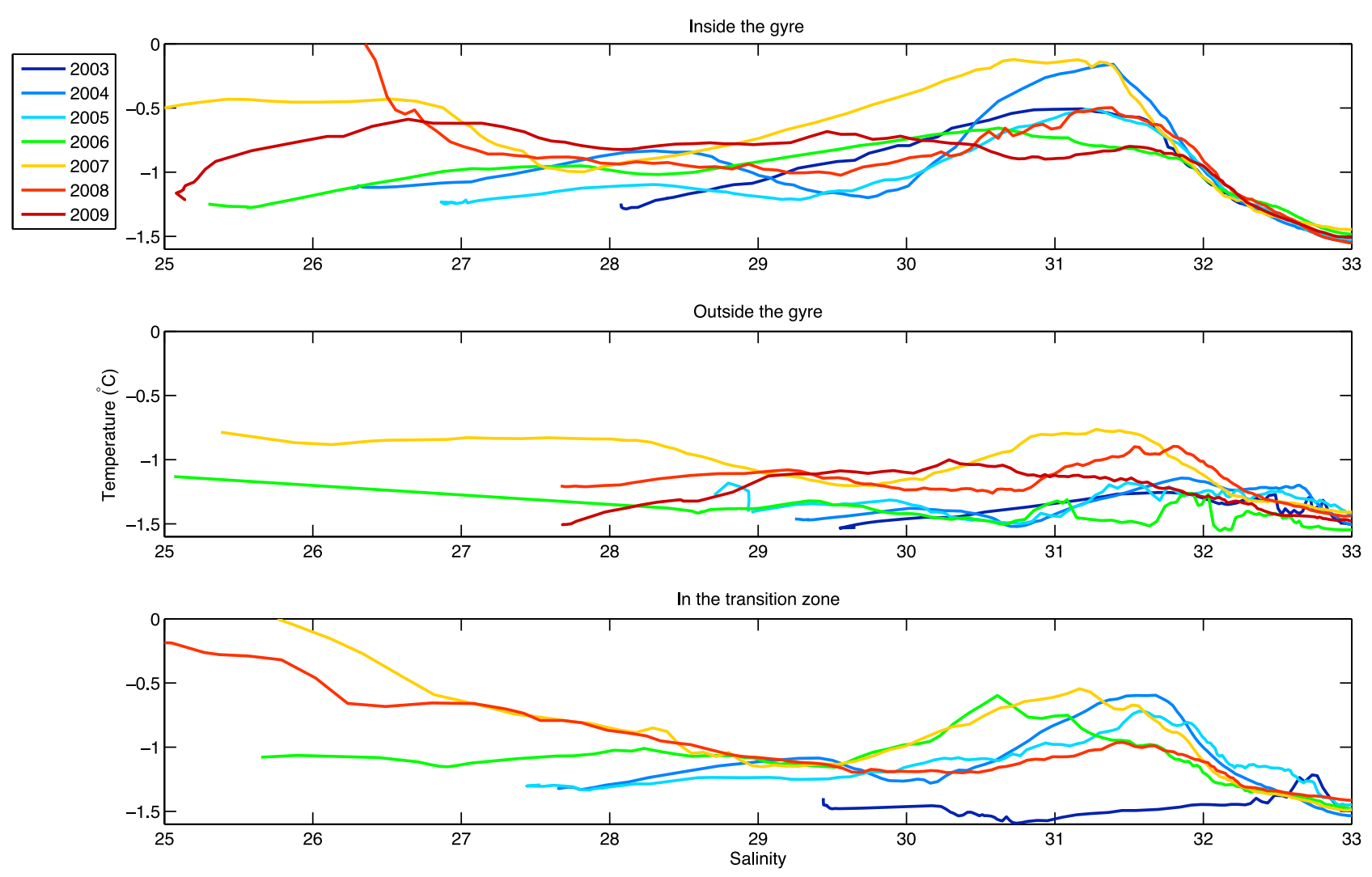

Figure 8. Average temperature-salinity plots for stations that were (top) inside the Beaufort Gyre, (middle) outside the Beaufort Gyre, and (bottom) in the transition zone for 2003-2009. Only stations with bottom depths greater than $3000 \mathrm{~m}$ were used to calculate the average. The number of stations used to calculate the average are presented in Table 2. The years 1993 and 2002 were not included because sparse sampling meant the location of the center of the Beaufort Gyre was uncertain.

Gyre. The depth of PSW inside of the gyre and in the transition zone deepened from 2003-2009 and 2004-2008, respectively (Figure 9c). This deepening was statistically significant $\left(\mathrm{p}\right.$-value $=0.03$ for the relationship $\mathrm{Z}_{P S W}=$ $5.305 \mathrm{~m}^{*}$ year $-10577 \mathrm{~m}$ ) only for stations inside the gyre. Outside of the gyre, the depth of PSW was more variable and was deepest in 2005 and 2008. In 2009, PSW inside the gyre remained at the 2008 depth while PSW in the transition zone and outside of the gyre shoaled by about $30 \mathrm{~m}$.

[28] The deepening of PSW inside the Beaufort Gyre and in the transition zone from 2006-2008 could be related to interdecadal climate variability that affects the circulation of the Beaufort Gyre, as described by the Arctic Ocean Oscillation index (AOO) [Proshutinsky and Johnson, 1997]. The AOO has two modes - a cyclonic regime where the Beaufort Gyre weakens and the Transpolar Drift strengthens and a anticylonic regime where the Beaufort Gyre strengthens and the Transpolar Drift weakens. During the anticyclonic regime more freshwater is stored in the Beaufort Gyre; during the cyclonic regime, that freshwater is largely released and exported through Fram Strait [Proshutinsky et al., 2002]. The AOO was anticyclonic from 1997-2008, with very high values for 2007 and 2008 [Overland, 2009; Arndt et al., 2010], and switched to a cyclonic mode in 2009 [Arndt et al., 2010]. The strengthened anticyclonic winds in 2007 [Arndt et al., 2010] led to enhanced Ekman pumping (downwelling) and increased freshwater storage within the
Beaufort Gyre [Proshutinsky et al., 2009]. In addition, the sea ice concentration (Figures 4 and 5) was lowest and the surface salinity (not shown) was lowest in 2007 and 2008. We suggest that the strong downwelling, increased river runoff and sea ice melt [Yamamoto-Kawai et al., 2009] led to increased freshwater storage inside the gyre from 2006-2008, which freshened the NSTM and rWML. This increased freshwater would likely cause PSW (unless it also freshened, see Section 5.1) to enter the Canada Basin at a deeper depth. PSW showed no depth change in 2009 inside of the gyre but shoaled in both the transition zone and outside of the gyre and this non-synchronized depth of PSW in 2009 could imply that it took longer for stations inside the gyre to be affected by the switch to the cyclonic regime. In other words, when the AOO regime switched, it took longer for freshwater that was piled up in the gyre (that caused PSW to descend) to be released and exported out of Canada Basin than freshwater that was in the transition zone or outside the gyre.

\section{Changes to Pacific Summer Water}

[29] In the previous sections we showed that the NSTM and rWML freshened and that the PSW temperature maximum also freshened from about $29.5-32$ in 2004 to $28-32$ in 2007. Has PSW itself freshened or have other waters merged with PSW to change the properties of the temperature 

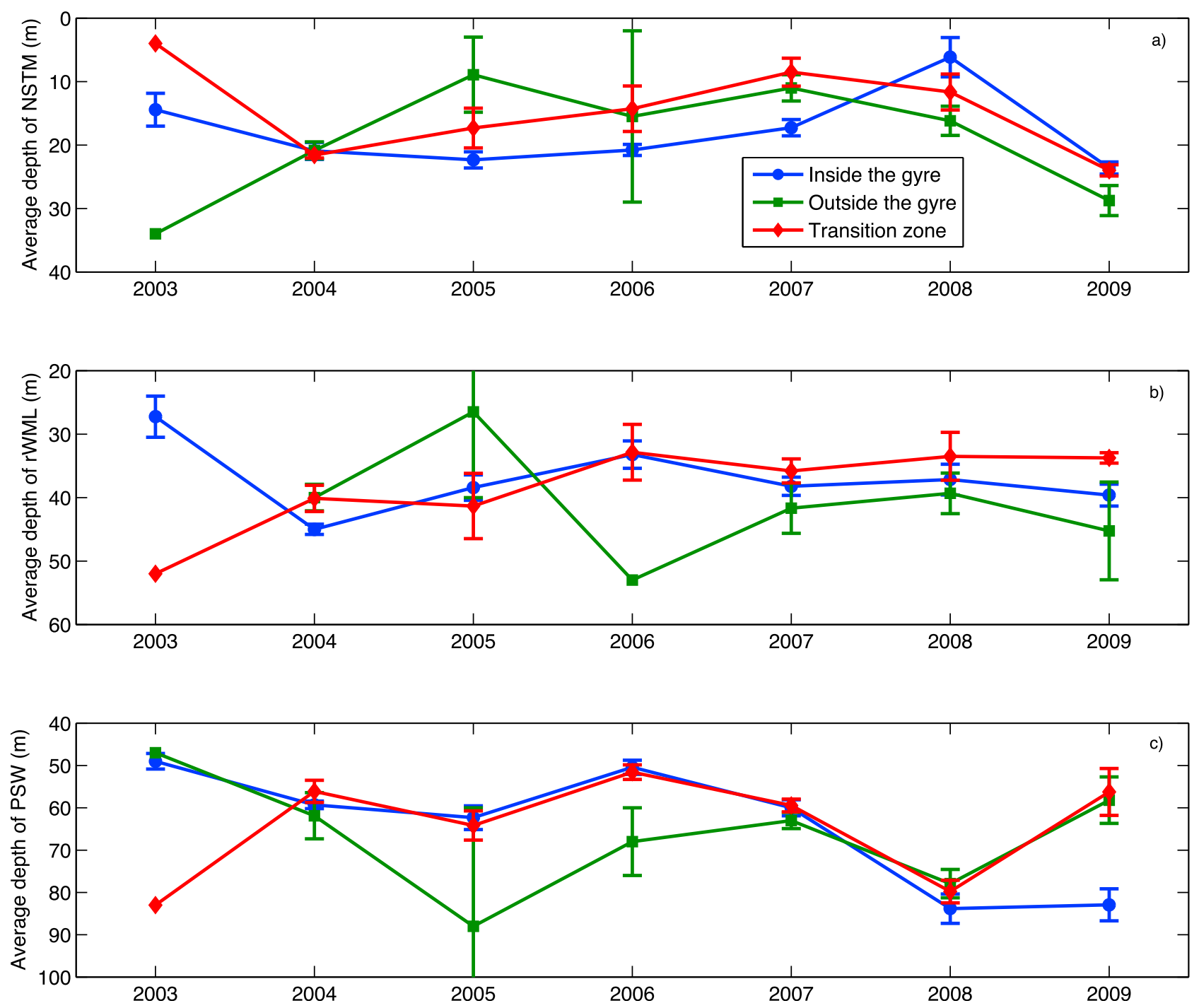

Figure 9. A comparison of the average depth of the (a) NSTM, (b) rWML, and (c) PSW from inside of the gyre (blue line), outside of the gyre (green line) and in the transition zone (red line) during the summers of 2003 to 2009 . The error bars represent the standard error for year and sample sizes are shown in Table 2. The years 1993 and 2002 were not included because sparse sampling meant the location of the center of the Beaufort Gyre was uncertain. Only stations that had a bottom depth greater than $3000 \mathrm{~m}$ were used to calculate the average.

maximum? Here, we propose and examine three possible mechanisms that could change these properties. The first is that the source waters of PSW have freshened so that PSW enters the Canada Basin along a less dense isopycnal. The second is that the velocity and advective pathways of PSW have changed - this would modify the amount and properties of PSW in the basin. The third is that the diffusion of heat and salt between the NSTM, rWML and PSW have changed and this would modify the properties of PSW.

\subsection{Changes to the Source Waters of Pacific Summer Water}

[30] There is significant interannual variability in the properties of the waters entering the Arctic through the Bering Strait [Woodgate et al., 2006, 2010]. The source of PSW in the Canada Basin is largely a combination of ACW and ACC [Shimada et al., 2001; Steele et al., 2004] that primarily enters the basin via Barrow Canyon [e.g., see Münchow and Carmack, 1997; Weingartner et al., 1998; Woodgate et al., 2005a]. Can we relate changes in the basin to changes in the salinity of the inflow?

[31] We first examined the interannual variability of PSW in the Canada Basin. Since we anticipate that PSW cools in the Arctic, rather than compare salinities at set temperatures, we compare salinities at the local temperature maximum. This temperature maximum was a consistent feature (it was observed in 201 out of 204 temperature profiles) so we simply found the salinity at the highest PSW temperature for each station. This salinity was plotted for all cruises (Figure 10) and the average salinity inside the gyre, outside the gyre and in the transition zone was calculated for 2003-2009 (Figure 11). The salinity at PSW ranged from about 30.6 to 32.0. From 2003-2008, these salinities were freshest inside the gyre (average 30.8 to 31.6 ) and, with the exception of an 

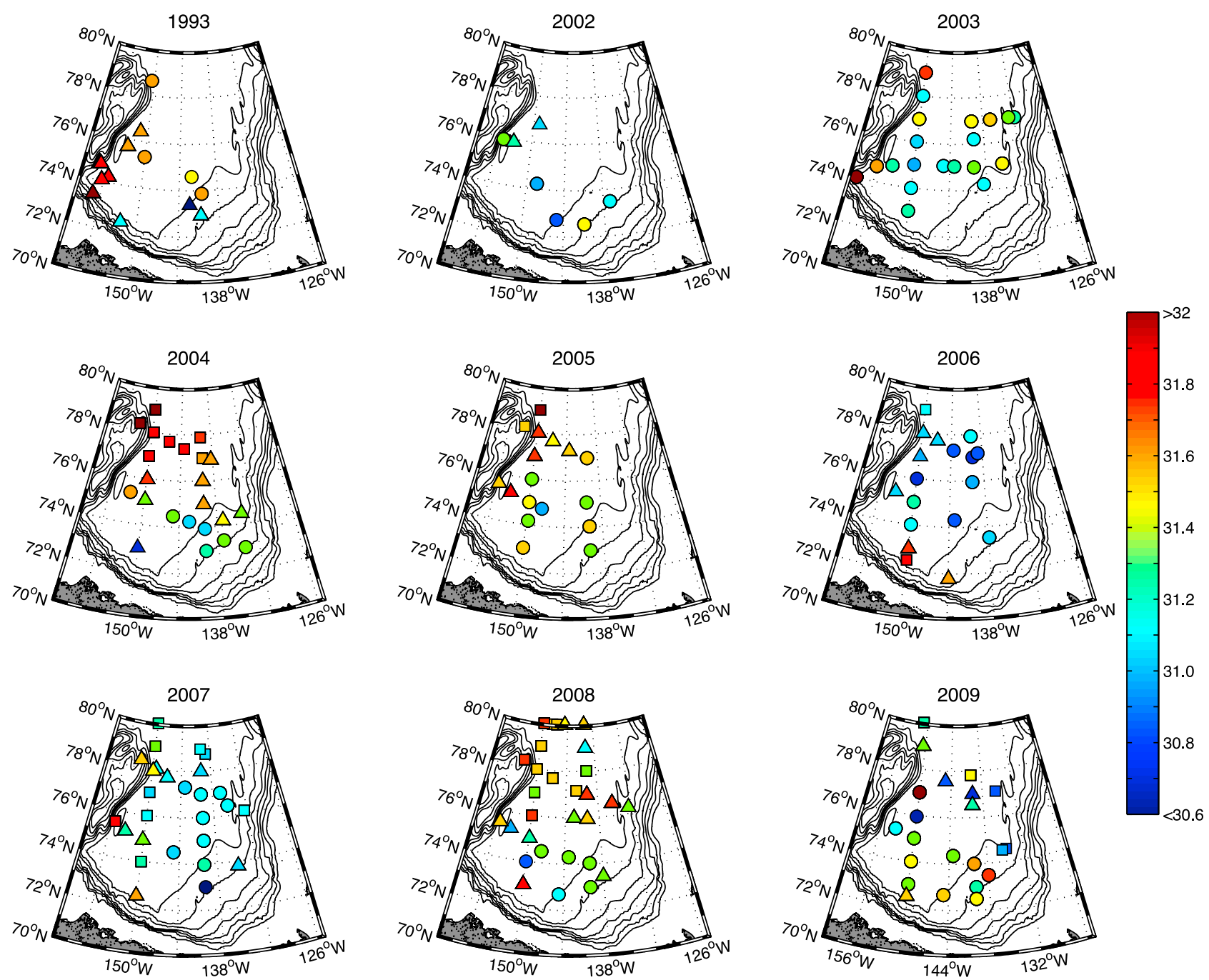

Figure 10. A comparison of the salinity at the temperature maximum that we call PSW collected during the cruises from 1993 through 2009. Colored circles represent stations that were inside the Beaufort Gyre , triangles represent stations that were in the transition zone, and squares represent stations that were outside of the gyre. Black lines show the bathymetry at $500 \mathrm{~m}$ intervals from $500 \mathrm{~m}$ to $3500 \mathrm{~m}$. Only stations that had a bottom depth great than $3000 \mathrm{~m}$ were considered.

anomalous point in 2003, saltiest outside the gyre (average 31.1 to 31.9 ). Considerable interannual variability was observed, with the freshest salinities throughout the basin in 2006 (average 31.0) and the saltiest in 2005 (average 31.6). In addition, the freshest salinities in 2006 were on the western side of the Canada Basin near the Northwind Ridge. This is the same region where Shimada et al. [2001] and Steele et al. [2004] observed the warmest PSW. Shimada et al. [2006] suggested this is because the warmest pulse of PSW is transported through Barrow Canyon at the same time of year that easterly winds become dominant, thereby pushing the warm PSW toward the western Canada Basin. It is thus likely that the region near the Northwind Ridge receives new PSW each year.

[32] To compare the source PSW to that in the Canada Basin, the monthly average salinity and temperature were calculated from moorings A2, A3 and A4 and the data were smoothed with a three month running mean. Of these moorings, the waters at $\mathrm{A} 3$ are coldest and saltiest and, due to the influence of the ACC, at A4 are warmest and freshest [Woodgate et al., 2006]. Figure 12 shows these data with the salinity and temperature of PSW at CB5 near the southern Northwind Ridge $\left(75.3^{\circ} \mathrm{N}, 153.3^{\circ} \mathrm{W}\right)$ during cruises 2002 09 . In salinity, these data indicate that $A 2$ and $A 4$ were in the same salinity range as our defined PSW at CB5, however anomalous salinity events (e.g., the water was anomalously fresh in 2004 at A4 but not at CB5) were not synchronous. This is not surprising given the significant transit times between these points. A3 was far saltier than our defined PSW and this suggests that waters found in central Bering Strait are not a source of PSW. In temperature, PSW at CB5 was much cooler than in the Bering Strait. This suggests substantial heat loss during transit from the Bering Strait into the Canada Basin that, as discussed by Woodgate et al. [2010], could affect sea ice and atmospheric conditions in the Chukchi Sea. Finally, Figure 12 shows that although the salinity of the PSW source waters vary interannually, there was no freshening 


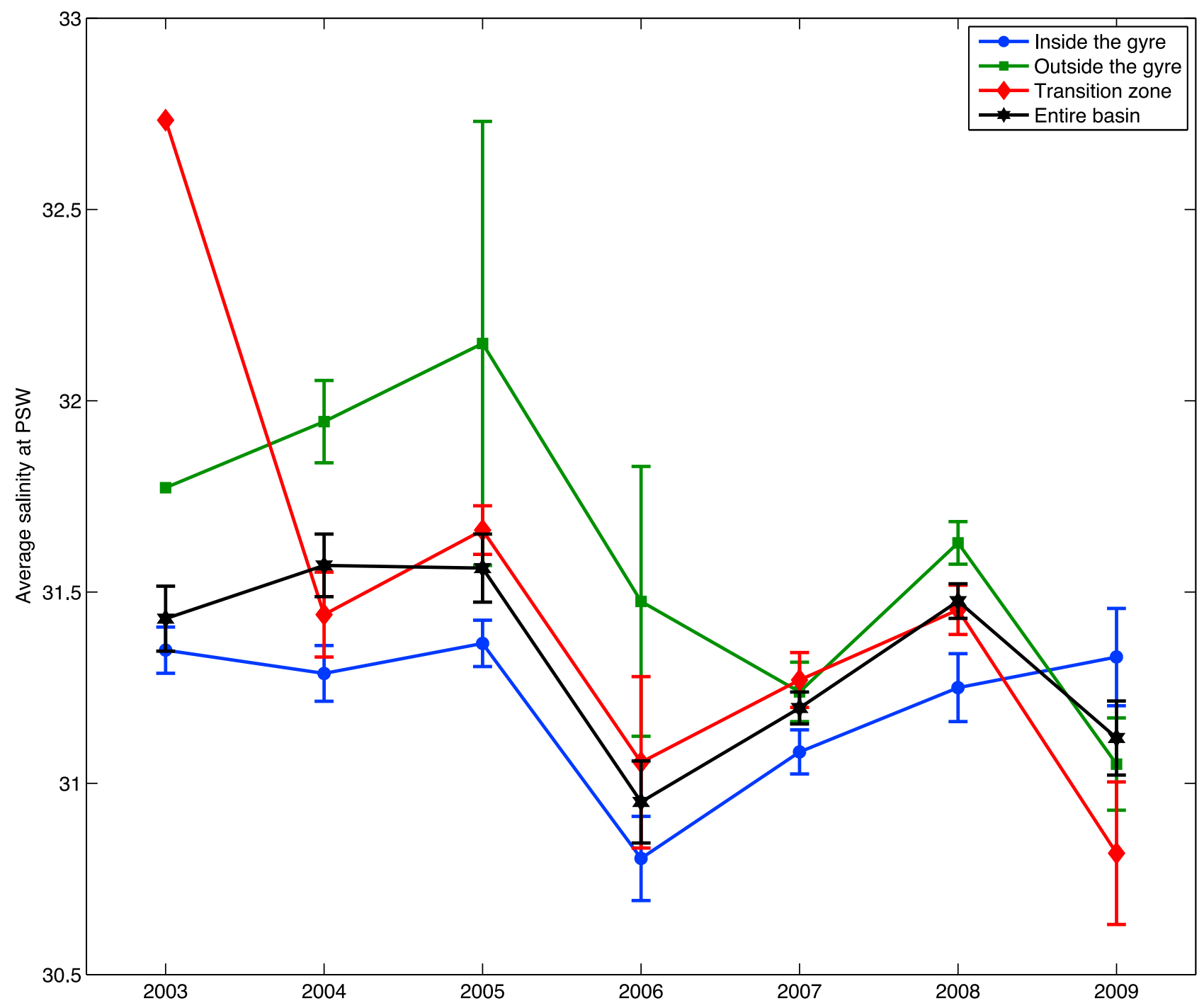

Figure 11. The average salinity (with standard error bars) at the temperature maximum of PSW from 2003-2009. The average salinity was calculated for stations inside the Beaufort Gyre (blue line), outside the gyre (green line), in the transition zone (red line), and for the entire Canada Basin (black line). Only stations that had a bottom depth great than $3000 \mathrm{~m}$ were considered.

trend over the study period that could account for the fresher PSW temperature maximum observed in the Canada Basin.

[33] This comparison leads us to two questions - i) Is PSW at station CB5 most influenced by ACC (A4) or ACW (A2)?; and ii) Can the transport time from Bering Strait to station CB5 be estimated? To address both questions, the average salinity and temperature mooring data from the months where the water had warm and fresh PSW properties (June through November) was calculated and a linear regression was run between the seasonally averaged mooring data and the summer data at CB5. It would take several months for water to cross the Chukchi Sea from the Bering Strait to Barrow Canyon [Woodgate et al., 2005b] and, given typical near-surface velocities in the Canada Basin of 1-5 $\mathrm{cms}^{-1}$ [Coachman and Barnes, 1961; Jahn et al., 2010], it would take a year or more for water to reach CB5 from Barrow Canyon, so data from the same year were not compared. Thus, CB5 data were first compared with Bering Strait data from the preceding year and no significant rela- tionship was found with this 1-year lag. Then, 2-year lagged data were considered (i.e., 2002 Bering Strait data were compared with 2004 CB5 data; see Figure 13). This time lag showed that both the salinity $\left(\mathrm{R}^{2}=0.99 ; S_{C B 5}=1.36^{*} S_{A 4}-\right.$ $11)$ and temperature $\left(\mathrm{R}^{2}=0.82 ; T_{C B 5}=0.843^{*} T_{A 4}-3.71^{\circ} \mathrm{C}\right)$ at CB5 were very well-correlated with the six month averaged salinity and temperature at mooring A4. A t-test with $\mathrm{N}=3$ degrees of freedom suggests such a correlation would be significant at the 90-95\% level. However, these statistics are done only on 4 data points, and are subject to a somewhat arbitrary choice of the time period of averaging of the A4 data and the station location in the Canada Basin. Thus, we conclude the correlation is suggestive, but more data are required to test this idea thoroughly.

[34] This analysis suggests that

[35] 1. During our study period, ACC (sampled at mooring A4) primarily influenced the properties of PSW in the southwestern Canada Basin. 

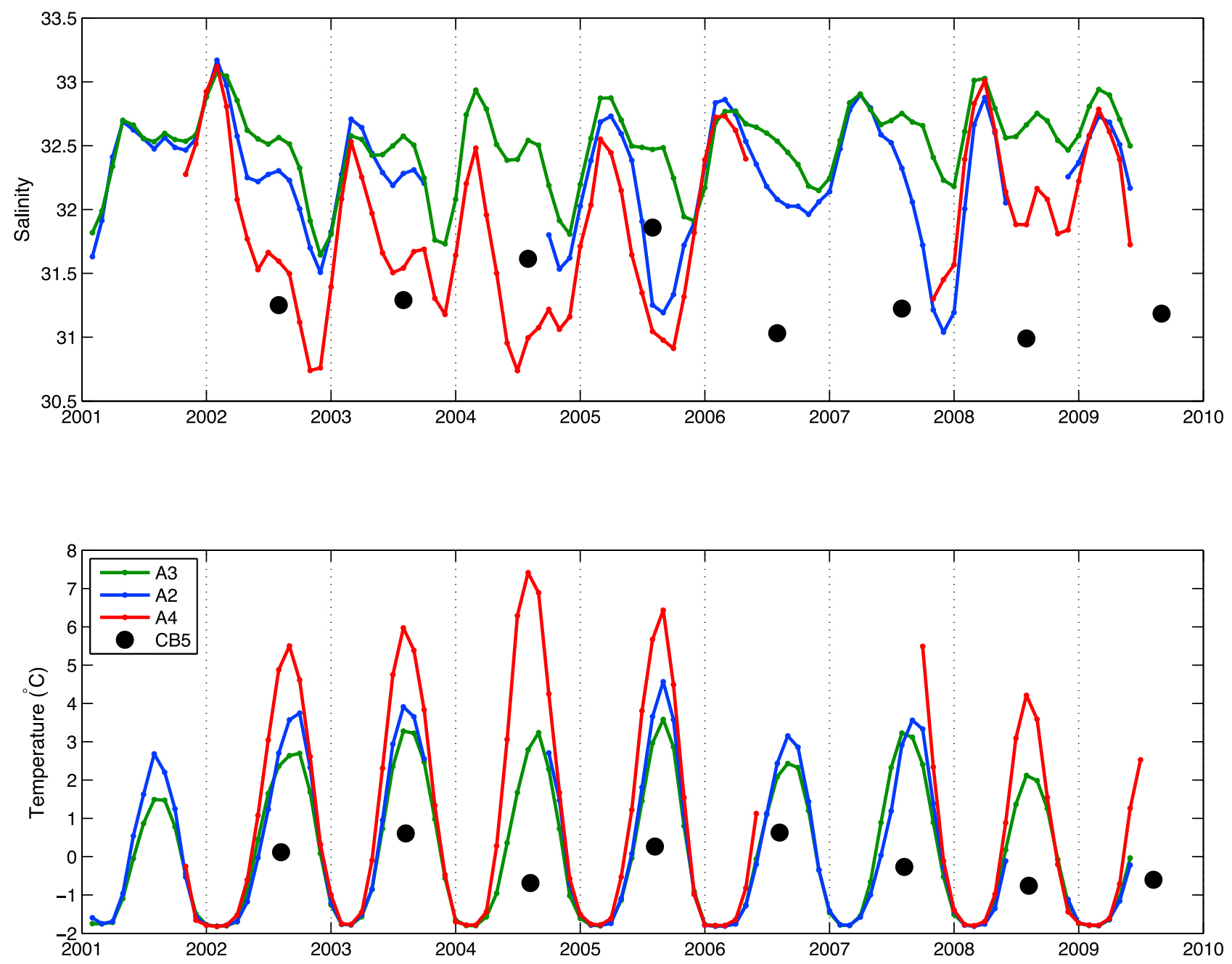

Figure 12. A comparison of the (top) salinity and (bottom) temperature at Bering Strait moorings A2, $\mathrm{A} 3$ and A4 with the salinity and temperature at station $\mathrm{CB} 5\left(75.3^{\circ} \mathrm{N}, 153.3^{\circ} \mathrm{W}\right)$ in the western Canada Basin. The mooring data were averaged monthly and smoothed with a 3 month running mean.

[36] 2. A transit time of 2 years (at an estimated velocity of $1-2 \mathrm{~cm} \mathrm{~s}^{-1}$ ) from the Bering Strait to the southern Northwind Ridge, at least during our study period, is possible.

[37] 3. Since the relationship between water at A4 and CB5 was so consistent, there was little interannual variation in mixing or pathways of PSW between the Bering Strait and CB5 during our study period.

[38] 4. ACC waters cooled and became saltier on their transit from A4 to CB5.

[39] 5. Although there was no obvious warming or freshening trend, changing ACC may have a large impact on PSW at CB5. For example, warm and fresh 2004 ACC waters caused the PSW to warm by about $0.5^{\circ} \mathrm{C}$ and freshen by about 0.5 salinity units from 2005 to 2006 .

\subsection{Changes to the Pathway and Velocity of Pacific Summer Water}

[40] About a third $(0.3 \mathrm{~Sv})$ of the $0.8 \mathrm{~Sv}$ Pacific water that crosses through Bering Strait is thought to enter the Canada Basin through Barrow Canyon [Coachman and Barnes, 1961; Woodgate et al., 2005b; Shimada et al., 2006]. Thus, changes in the transport through Barrow Canyon could alter the properties of PSW within the basin. The water flowing through Barrow Canyon, which is several months downstream of Bering Strait [Woodgate et al., 2005b; Panteleev et al., 2010], is warm enough and fresh enough to be classed as PSW by our definition from the end of July through the beginning of November [Aagaard and Roach, 1990; Woodgate et al., 2005b]. Transport through Barrow Canyon into the basin has been estimated as an annual average of $0.14 \pm 0.5 \mathrm{~Sv}$ [Woodgate et al., 2005b] or $0.3 \mathrm{~Sv}$ during summer and fall [Münchow and Carmack, 1997; Nikolopoulos et al., 2009; Watanabe and Hasumi, 2009]. Münchow and Carmack [1997] found that PSW will follow three pathways out of Barrow Canyon - one that travels eastward along the shelf, one that travels eastward along the slope, and one that turns north into the Canada Basin. It has been estimated that the eastward slope current transports about $0.13 \mathrm{~Sv}$ at a velocity of $5-10 \mathrm{~cm} \mathrm{~s}^{-1}$ from mid-August to the beginning of October [Nikolopoulos et al., 2009]. Mechanisms that transport PSW from the slope out into the Canada Basin are largely unknown, although it has been suggested that hydrodynamic instabilities of the Barrow Canyon outflow and the slope current can form basin-bound 

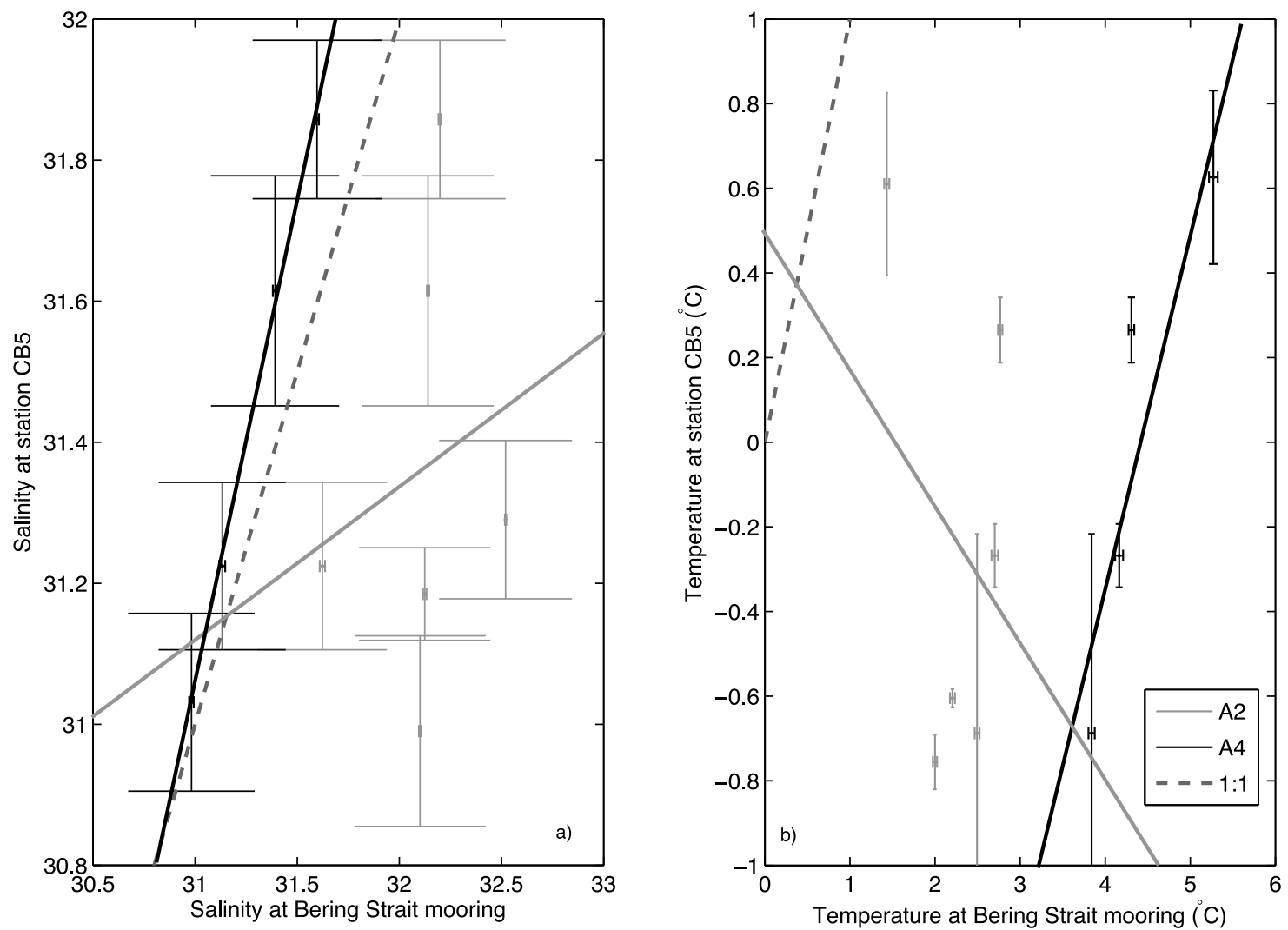

Figure 13. Linear regression with standard error between the 6 month average (June through November) from moorings A2 (grey points) and A4 (black points) - the horizontal axes - and the PSW properties at station CB5 (the vertical axes). For the horizontal axes, standard error (represented by error bars) was calculated from the 6 months of mooring data and $\mathrm{n}$ was 5022. For the vertical axes, standard error was calculated from CB5 and the 4 stations closest to it - each station was 100-300 km from CB5- and $\mathrm{n}$ was 5 . Here we compared the (a) salinity and (b) temperature data from CB5 to data from the Bering Strait moorings that were collected 2 years before. Solid lines represent the best fit between each different mooring and station CB5. Dashed grey line is the 1:1 ratio of the properties.

eddies [D'Asaro, 1988; Pickart, 2004; Nikolopoulos et al., 2009]. Also, upwelling events (that are most prevalent in late fall [Pickart, 2004]) could feasibly move waters from the slope current into the basin. The fate of PSW that travels along the shelf is largely unknown but its properties are likely modified in fall and winter as sea ice forms.

[41] The velocity of PSW that flows northward from Barrow Canyon into the Canada Basin has been estimated (based on 2 days in September 1993) as $5-10 \mathrm{~cm} \mathrm{~s}^{-1}$ [Münchow and Carmack, 1997] although specific details of this transport is unknown. Using a model, Watanabe and Hasumi [2009] suggested that more PSW is transported into the Canada Basin in summer when the sea ice concentration is reduced. They argue that reduced sea ice accelerates flow through Barrow Canyon, thereby creating more instabilities that form eddies that travel into the basin. Similarly, a simulation by Steele et al. [2010] found that Pacific water traveled further into the Canada Basin in 2007 than 2000-2006 and they suggest that the minimal 2007 sea ice cover led to faster spreading of PSW. Despite these observations or models suggesting interannual change in pathways near Barrow Canyon, the strong correlation we find between PSW properties at mooring A4 and station CB5 suggests that the modification of PSW properties between these points does not show significant interannual change.

[42] PSW modification within the gyre was examined using a 1-D model of heat and salt diffusion (see Section 2.6 for details). After it leaves the southern Northwind Ridge, PSW is thought to be transported as part of the anticyclonic Beaufort Gyre [Coachman and Barnes, 1961; Steele et al., 2004; Shimada et al., 2006]. Station CB21 is downstream of CB5 and was within the gyre for every year of the study period (Figure 6). We compared PSW properties from its young form at station CB5 (given the high correlation between mooring A4 and station CB5 found in Section 5.1) downstream to station CB21 inside the gyre. Heat and salt diffusion were estimated using a weaker $\left(\kappa=1 \times 10^{-6} \mathrm{~m}^{2} \mathrm{~s}^{-1}\right)$ and stronger $\left(\kappa=3 \times 10^{-6} \mathrm{~m}^{2} s^{-1}\right)$ term for each summer cruise from station $\mathrm{CB} 5$ for 1 year and then compared to data from station CB21 sampled during the following cruise (Figure 14). We found that, with the exception of 2009, PSW at station CB5 was always cooler than at station CB21 and this suggests that a pathway from the Northwind Ridge to the Canada Basin is correct. In general, the observed properties at CB21 were quite similar to those at CB5 one year earlier. For example, the warm PSW observed at CB5 in 2003 was seen in 2004 at CB21 and the cold PSW observed at CB5 in 2004 was 

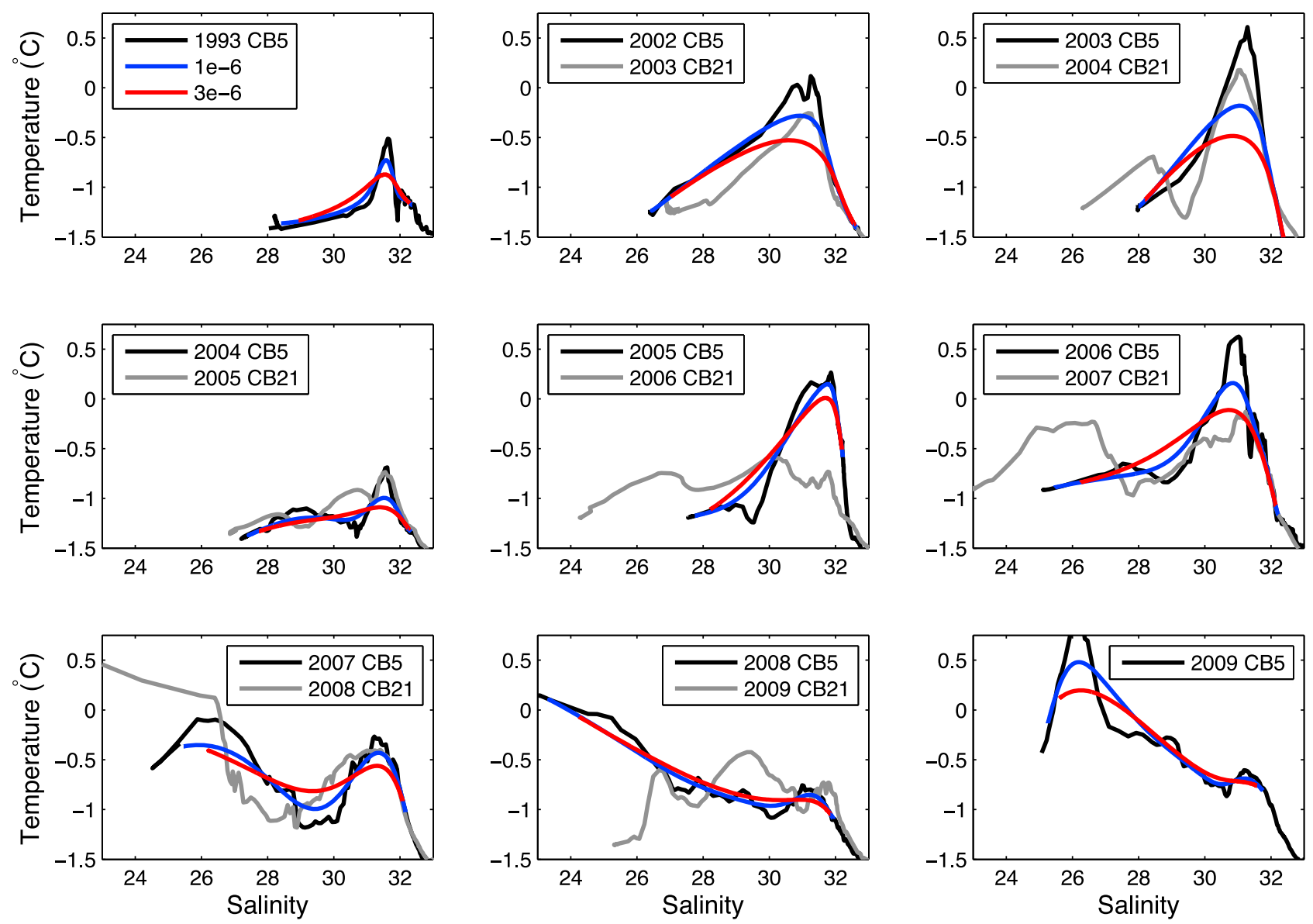

Figure 14. Temperature-salinity diagram of the upper $100 \mathrm{~m}$ for station $\mathrm{CB} 5\left(75.3^{\circ} \mathrm{N}, 153.3^{\circ} \mathrm{W}\right.$, solid black line) and station $\mathrm{CB} 21\left(74^{\circ} \mathrm{N}, 140^{\circ} \mathrm{W}\right.$, solid grey line) one year later. PSW travels from station CB5 to $\mathrm{CB} 21$ in the anticyclonic Beaufort Gyre so heat and salt should diffuse from CB5 to CB21. The diffusion of heat and salt from station CB5 were estimated from a 1-D vertical diffusion model calculated using a central derivative finite difference. The model was run separately for 1 year with two different diffusivities - $1 \times 10^{-6} \mathrm{~m}^{2} \mathrm{~s}^{-1}$ (solid blue line) and $3 \times 10^{-6} \mathrm{~m}^{2} \mathrm{~s}^{-1}$ (solid red line).

seen in 2005 at CB21. This suggests that it takes about 1 year to transport PSW from the southern Northwind Ridge to the center of the gyre at a velocity of about $1 \mathrm{~cm} \mathrm{~s}^{-1}$. This estimate is within the range of $1-5 \mathrm{~cm} \mathrm{~s}^{-1}$ observed by Coachman and Barnes [1961] and less than the $5 \mathrm{~cm} \mathrm{~s}^{-1}$ found by Jahn et al. [2010].

[43] There were instances when our modeled diffusion could not explain changes to PSW during transit from CB5 to $\mathrm{CB} 21$. For example, there was less diffusion than our model predicted from 2003 at CB5 to 2004 at CB21 and 2004 at CB5 to 2005 at CB21. Less diffusion could imply that PSW propagated faster. There was more diffusion than our model predicted from 2005 at CB5 to 2006 at CB21 and from 2006 at CB5 to 2007 at CB21. More diffusion could suggest that PSW propagated slower or could suggest the intrusion of colder water between CB5 and CB21. However, the observed heat loss from CB5 to CB21 was most similar to the modeled heat loss with a diffusivity of $1 \times 10^{-6} \mathrm{~m}^{2} s^{-1}$, so we suggest that this smaller value gives the best estimate of PSW heat loss due to diffusion.

[44] Although several mechanisms have been proposed for changing the velocity and pathway of PSW once it leaves the Chukchi Sea (the pathway of PSW at the mouth of Barrow Canyon [Münchow and Carmack, 1997], the sea ice cover offshore of Barrow Canyon [Watanabe and Hasumi, 2009; Steele et al., 2010], and the strength of the Beaufort Gyre [Steele et al., 2004]), we found no evidence that this happened during our study period. The high correlation of properties between mooring A4 in Bering Strait and station CB5 near the southern Northwind Ridge suggests (for the years examined) that transport time between these regions did not change. In addition, although there was interannual variability (e.g., PSW appeared to propagate faster from 2003 at CB5 to 2004 at CB21 and propagate slower from 2005 at CB5 to 2006 at CB21), changes to PSW between station CB5 and station CB21 inside of the gyre can partly be explained by vertical heat diffusion over $\sim 1$ year, and there was little evidence for systematic change in the velocity or pathway to PSW during our study period.

\subsection{Heat Diffusion From NSTM and PSW to the rWML}

[45] In previous sections, we found that the NSTM has warmed and freshened (Figure 2), that the rWML has warmed and freshened (Figures 4 and 5), and that the PSW temperature maximum has freshened (Figure 8). These 

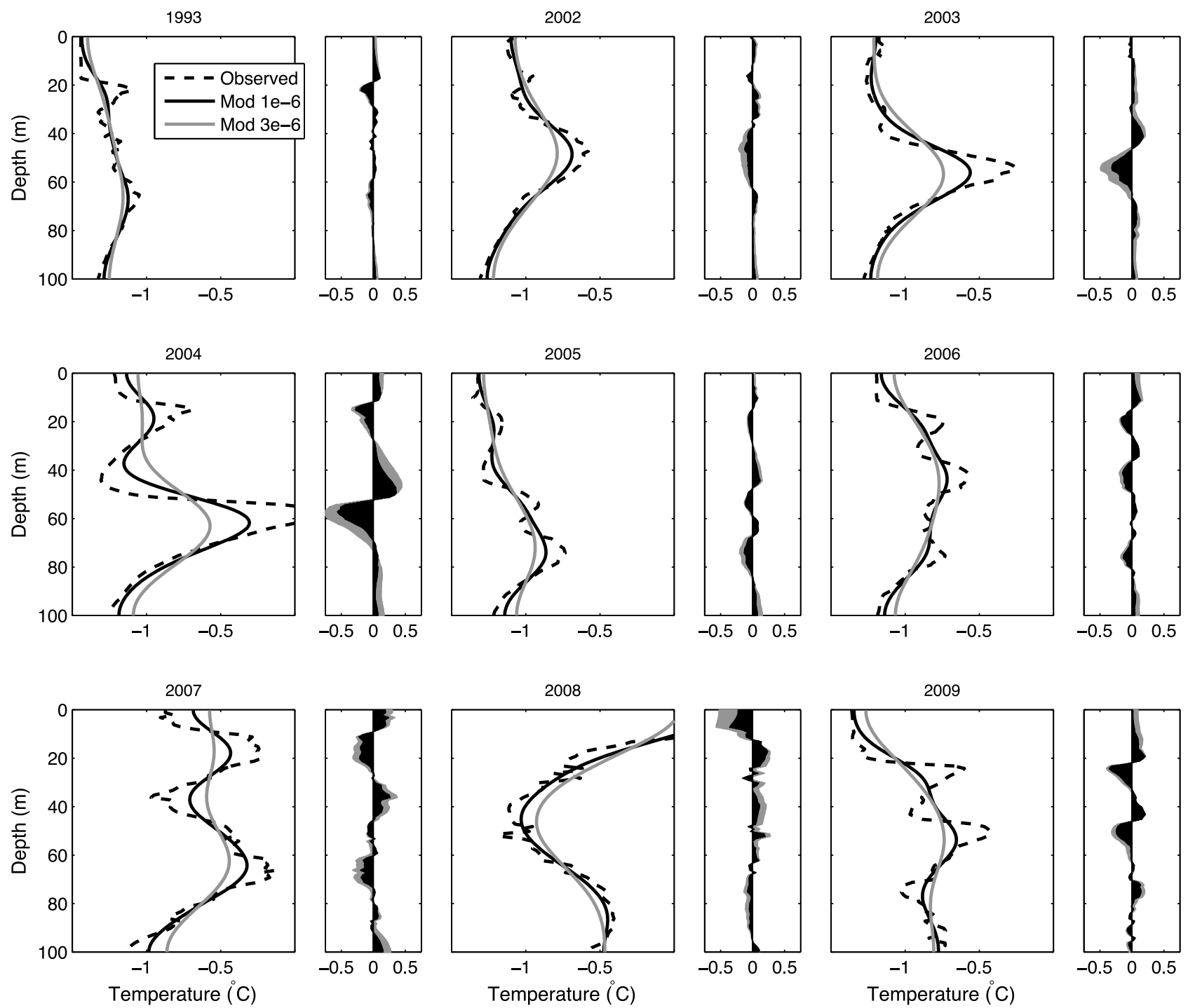

Figure 15. An estimate of vertical heat diffusion at station CB21 (74 $\left.{ }^{\circ} \mathrm{N}, 140^{\circ} \mathrm{W}\right)$ for 1993 and 2002-09. Using a central derivative finite difference, the heat equation was calculated in the upper $100 \mathrm{~m}$ for 1 year. The model was initialized to the observed temperature profile (dashed black line) for each year. Two experiments were run, one where the diffusivity $(\kappa)$ was $1.0 \times 10^{-6} \mathrm{~m}^{2} \mathrm{~s}^{-1}$ (solid black line) and one where $\kappa$ was $3.0 \times 10^{-6} \mathrm{~m}^{2} \mathrm{~s}^{-1}$ (solid grey line). The horizontal bar graphs show where the temperature increased or decreased in $1 \mathrm{~m}$ increments within the range $-0.75^{\circ} \mathrm{C}$ to $0.75^{\circ} \mathrm{C}$.

changes were greatest at stations located within the Beaufort Gyre. Since more heat has been stored below the summer halocline in recent years [Jackson et al., 2010a], it is possible that some changes could have been caused by the diffusion of heat and salt between the NSTM, rWML and PSW.

[46] To estimate heat diffusion, a 1-D model was run for 1 year (Figure 15). The model was run for data from station CB21 since this station was located within the gyre each year. This is different than the comparison in section 5.2 because here we examine changes in rWML waters that remain inside of the gyre whereas in section 5.2, we examined changes to PSW as it is advected into the gyre. In general, over 1 year, the temperature change was about double that for the higher diffusivity (e.g., PSW in 2004 cooled by about $0.25^{\circ} \mathrm{C}$ with the lower diffusivity and $0.5^{\circ} \mathrm{C}$ with the higher diffusivity). The rWML gained heat each year while the overlying NSTM and underlying PSW lost heat. The model showed that from 2002-05, the greatest heat loss was from PSW and the greatest heat gain was for the rWML. Beginning in 2006, heat loss from the NSTM became equally important to that lost from PSW. Our model also shows that some of the heat lost from the NSTM was gained in the surface mixed layer, which suggests that a small amount of diffusion can bring some heat from the NSTM into contact with sea ice [Shimada et al., 2001] even though Toole et al. [2010] found that a much larger diffusivity is needed to completely erode the summer halocline. From these model results, we speculate that much of the warming of the rWML observed since 1993 

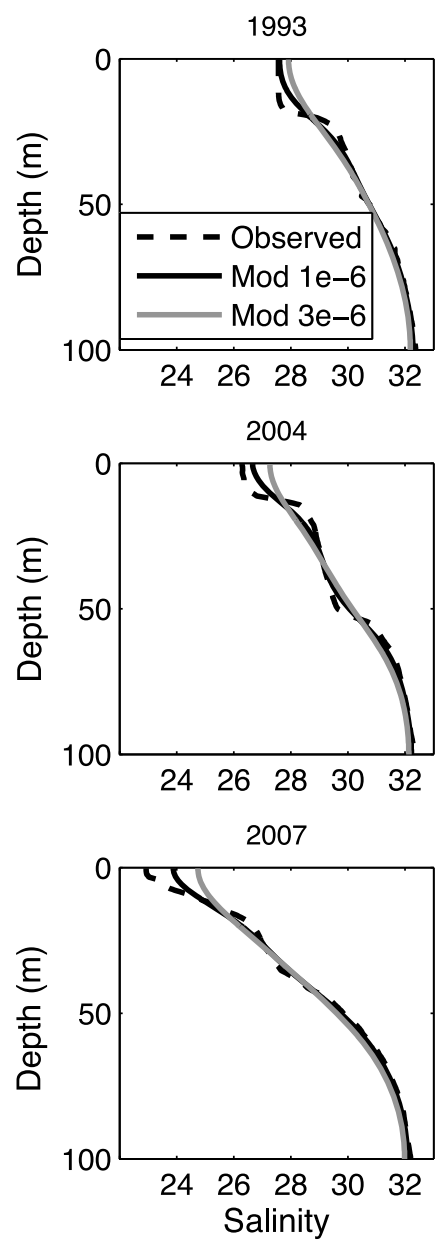
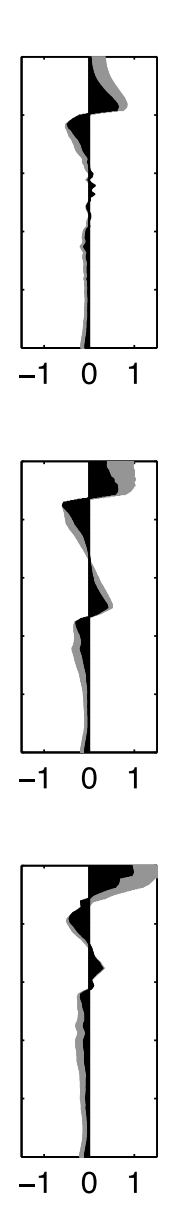
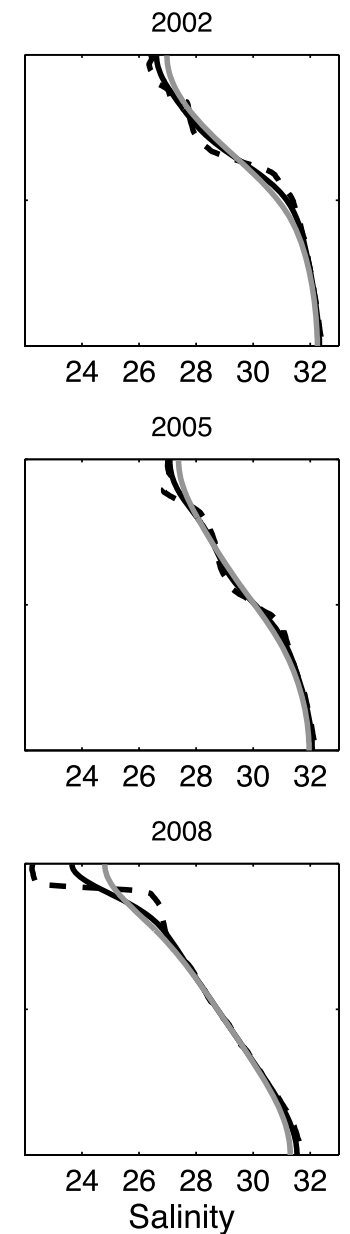
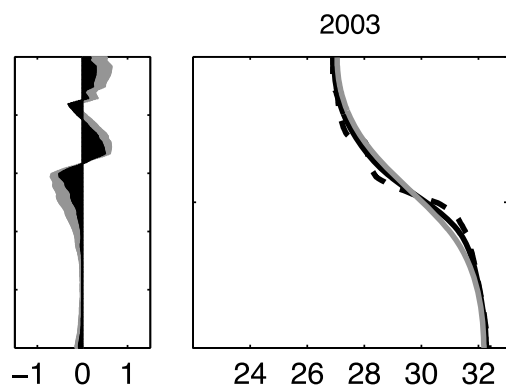

$\begin{array}{lllll}24 & 26 & 28 & 30 & 32\end{array}$

2006
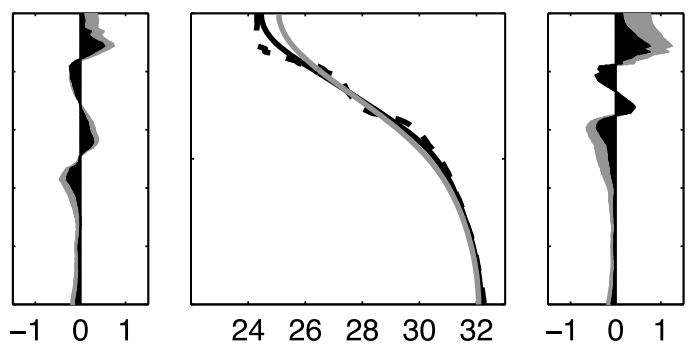

2009
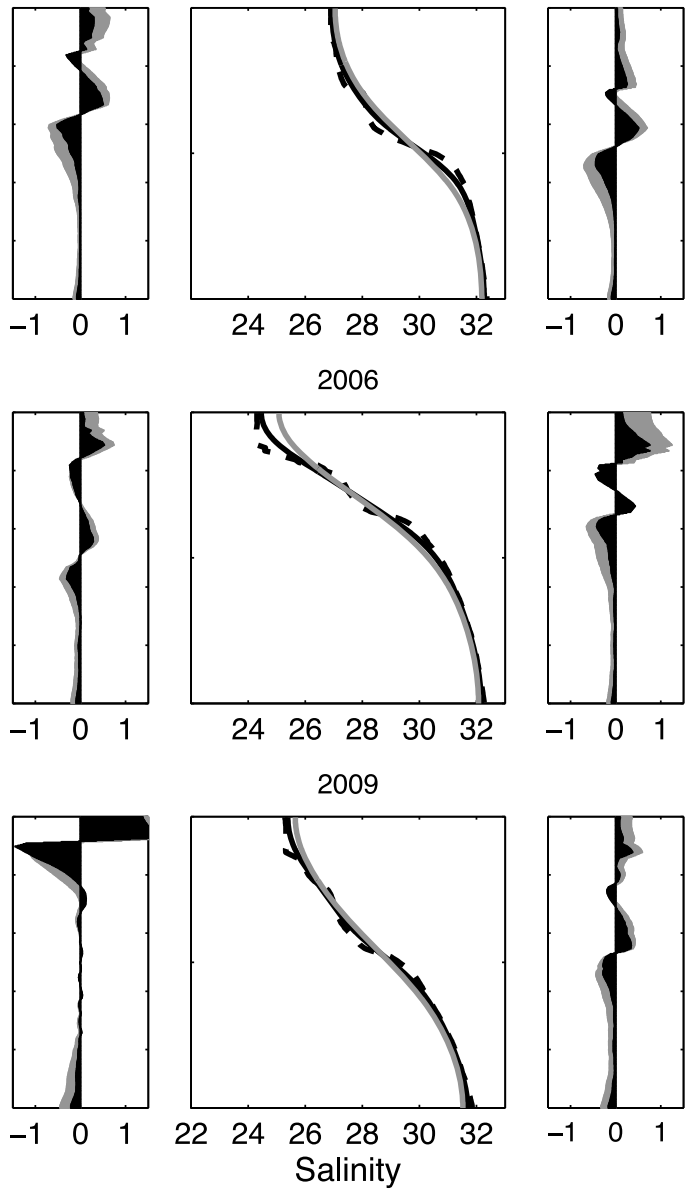

Figure 16. As in Figure 15 but for salt diffusion. The model was initialized to the observed salinity profile (dashed black line) for each year. The salinity range of the horizontal bar graphs is -1.5 to 1.5 salinity units.

might be attributed to heat diffusion from both the NSTM and PSW, with more heat being contributed from the NSTM since 2006. These results also imply that a diffusivity of $3 \times$ $10^{-6} \mathrm{~m}^{2} \mathrm{~s}^{-1}$ explains most of the heat gained by the rWML over 1 year. This is because the rWML usually disappears during winter (Figure 3) and the higher diffusivity is more realistic in smoothing out the rWML. The higher required diffusivity here compared to that for PSW (section 5.2) is consistent with the expected pattern of higher diffusivities nearer the surface.

[47] The model was also used to estimate salt diffusion for 1 year (Figure 16). In the model, the greatest changes were seen above and below the summer and winter haloclines, with salt lost below each halocline and gained above it. In the model, PSW became fresher, the rWML became saltier (by up to 0.5 salinity units in 2002), the NSTM became fresher and the surface mixed layer became saltier. However, this is contrary to the observations which show freshening. We found that, in general, the observed warming of the rWML is comparable in magnitude to what one would expect from diffusion (Figure 15). However, the same strength of diffusion for salt shows an increase in salinity of the rWML, rather than the observed freshening. This sug- gests that, in addition to diffusive change, there is likely some accumulation of freshwater. It is important to note this is a very simple model, and contains no dynamics, no diffusion changes due to stratification, no freeze-melt cycle, and no wind mixing. In addition, the no-flux boundary conditions at the surface are likely erroneous, and neglect important fluxes of salt/freshwater.

[48] These simple model tests suggest that a combination of diffusion and accumulation of freshwater may be used to explain heating and freshening of the rWML during our study period. It is likely that the warming of the rWML, first noticed in 2006 (Figures 2, 4, and 8) was linked to the warming of the NSTM that was caused by the increased absorption of solar radiation following the reduction in sea ice extent. The freshening of the rWML was different and was likely caused by the freshening of near-surface waters from increased river runoff, sea ice melt, and interannual changes to the strength of the Beaufort Gyre. The accumulation of freshwater within the Beaufort Gyre intensified the freshening and warming of the rWML because it was formed at fresher salinities and because the higher stratification trapped more heat in the NSTM [Jackson et al., 2010a] that can later diffuse to the rWML. Since there 
was no freshening trend of PSW entering the Canada Basin and since the velocity and pathway of PSW seems not to have changed, we can conclude that the freshening of the PSW temperature maximum was caused by the freshening of the rWML. The water mass structure from 2009 was different, with 3 temperature maxima inside the basin. Our 1-D diffusion model predicts that these temperature maxima will diffuse into one temperature maximum by the summer of 2010 .

\section{Discussion and Summary}

[49] The near-surface waters of the Canada Basin changed dramatically from 1993-2009. These changes include the warming and freshening of the rWML and the NSTM, the apparent freshening of the PSW temperature maximum, and the appearance of a third temperature maximum and second temperature minimum in 2009. We used CTD, mooring and sea ice concentration data and a 1-D model of heat and salt diffusion to examine several possible processes that could account for these changes.

[50] The 1-D heat diffusion model suggested that heat may be diffused from the NSTM and PSW to warm the rWML, however diffusion cannot explain the observed freshening of the rWML, and suggests instead that the accumulation of fresher water is also necessary. Before 2006, most of the heat to warm the rWML was diffused from PSW. Since 2006, heat to warm the rWML was diffused from both the NSTM and PSW. Thus, the warming of the NSTM through reduction of sea ice melt and the increased absorption of solar radiation indirectly warmed the rWML (estimated at 30-50 $\mathrm{m}$ in summer).

[51] Our results suggest that the salinity of the rWML was associated with the location of the Beaufort Gyre. It is likely that shifts in the location of the gyre can be attributed to changes in surface winds [Overland, 2009; Proshutinsky et al., 2009]. It was found that the rWML was on average 1.9 salinity units fresher inside the gyre than outside of the gyre. Results from the 1-D model showed that salt diffusion would actually increase the salinity of the rWML. Thus, we suggest that the freshening of the rWML and NSTM was caused by a combination of sea ice melt and the repositioning of the Beaufort Gyre.

[52] Three different processes were examined to explain the freshening of the PSW temperature maximum. The first theory was that the source waters of PSW were freshening. To investigate this, the properties at three moorings in the Bering Strait were examined and no obvious freshening trend was observed. The second theory was that the advective pathway and velocity of PSW between Barrow Canyon and the Canada Basin had changed. There are many uncertainties in this transport, however, changes to the properties between Bering Strait and station CB5 (near the southern Northwind Ridge) and CB5 and station CB21 (in the southeastern Canada Basin) were similar and this suggests that there was little variation of PSW transport during our study period. The third theory was that diffusion changed the properties of PSW. Our model showed that once in the basin, PSW should be freshening because salt diffuses across the winter halocline from PSW to the rWML. The salt gradient between PSW and rWML increased in the past decade because the rWML freshened from sea ice melt. Thus, the fresher PSW temperature maximum can be explained by increased diffusion to the freshened rWML. These results show that surface warming and subsequent ice melt affect the water column to at least the depth of PSW.

[53] The deepening of the nutrient-rich Pacific waters in the center of the Beaufort Gyre will likely alter the local ecosystem. Jackson et al. [2010b] showed that the chlorophyll maximum deepened by $16 \mathrm{~m}$ from 2003 through 2008 . This deepening can be explained by either increased solar radiation (from decreased sea ice cover) that would support phytoplankton at deeper depths or the deepening of the nutricline. Nutrient data from the same cruises show that the nutricline is deepening [McLaughlin and Carmack, 2010] and this trend helps explain why the food web structure transitioned to smaller picoplankton [ $\mathrm{Li}$ et al., 2009] that have a competitive advantage over larger cells in low nutrient regimes [Agawin et al., 2000]. Picoplankton mainly support the microbial loop [Barber, 2007] that exports less carbon for grazing and burial than a nanoplankton-based food web [Li et al., 2009]. Thus, the changes we found to the water mass structure of the Canada Basin interior that are largely caused by sea ice melt under anticyclonic conditions [McLaughlin and Carmack, 2010] also impact the food web structure and the sequestration of carbon.

[54] During our study period from 1993-2009, the sea ice cover of the southern Canada Basin was drastically reduced from being perennially ice-covered in 1993 to almost icefree in the summers of 2007-2009 [Arndt et al., 2010, Figures $4 \mathrm{~g}$ and $4 \mathrm{~h}]$. During this time, we witnessed the rapid warming of the NSTM and rWML and by 2009, three temperature maxima and two temperature minima were present. Our heat diffusion model suggests that during the winter of 2009-2010, all of these features merged into one temperature maximum and this prediction was confirmed by data from ITP33 (not shown). ITP33 also showed that an NSTM formed above the one temperature maximum during the summer of 2010. Is this one temperature maximum in winter and two temperature maxima in summer the end state of the transition of Canada Basin's near-surface water mass structure? Will these temperature maxima continue to warm as summer sea ice melt traps and then stores solar radiation? Will heat from these temperature maxima melt ice throughout winter? How will these changes affect primary production and the ecosystem structure of the Canada Basin? These questions and many more are sure to arise as the Canada Basin continues its transition to a seasonally icefree ocean.

[55] Acknowledgments. Ship-based CTD measurements were supported by the Northern Oil and Gas Action Program (1993), the Joint Western Climate Arctic Study (2002-2006), and the Canadian International Polar Year Canadas Three Oceans project (2007-2009). We acknowledge financial and ship time support from Fisheries and Oceans Canada, the U.S. National Science Foundation's Beaufort Gyre Exploration Project and its PI Andrey Proshutinsky, the National Sciences and Engineering Research Council of Canada, the Northern Scientific Research Program of Canada, and collaboration with the Japan Agency for Marine-Earth Science and Technology. The Ice-Tethered Profiler data were collected and made available by the Ice-Tethered Profiler Program based at the Woods Hole Oceanographic Institution (http://www.whoi.edu/itp). The sea ice concentration data were made available by the National Snow and Ice Data Center (http://nsidc.org). The Bering Strait mooring data were collected under 
NSF, NOAA, ONR, and AOOS funding and made available by the Bering Strait: Pacific Gateway to the Arctic program (http://psc.apl.washington. edu/HLD/Bstrait/bstrait.html), supported currently by NSF-IPY0632154, AON-0855748 and NOAA RUSALCA. We deeply appreciate the assistance and support of the men and women of the Canadian Coast Guard icebreakers Louis S St Laurent and Sir Henry Larsen for their assistance with deploying the ITPs and collecting CTD data and chief scientists S. Zimmerman, J. Eert, B. Van Hardenberg, and J. Swift.

\section{References}

Aagaard, K., and A. T. Roach (1990), Arctic Ocean-shelf exchange: Measurements in Barrow Canyon, J. Geophys. Res., 95(C10), 18,163-18,175.

Agawin, N. S. R., C. M. Duarte, and S. Agusti (2000), Nutrient and temperature control of the contribution of picoplankton to phytoplankton biomass and production, Limnol. Oceanogr., 45(3), 591-600.

Arndt, D. S., M. O. Baringer, and M. R. Johnson (2010), State of the climate in 2009, Bull. Am. Meteorol. Soc., 91(7), S1-S222.

Barber, R. T. (2007), Picoplankton do some heavy lifting, Science, 315(5813), 777-778.

Carmack, E. C., R. W. Macdonald, and S. Jasper (2004), Phytoplankton productivity on the Canadian Shelf of the Beaufort Sea, Mar. Ecol. Prog. Ser., 277, 37-60.

Cavalieri, D., C. Parkinson, P. Gloersen, and H. J. Zwally (1996), Sea Ice Concentrations From Nimbus-7 SMMR and DMSP SSM/I Passive Microwave Data, http://nsidc.org/data/nsidc-0051.html, Natl. Snow and Ice Data Cent., Boulder, Colo. [Updated 2008.]

Coachman, L. K., and C. A. Barnes (1961), The contribution of Bering Sea water to the Arctic Ocean, Arctic, 14, 146-161.

D'Asaro, E. (1988), Observations of Small Eddies in the Beaufort Sea, J. Geophys. Res., 93(C6), 6669-6684.

Denman, K. L., and A. E. Gargett (1995), Biological-physical interactions in the upper ocean: The role of vertical and small scale transport processes, Ann. Rev. Fluid Mech., 27, 225-255.

Gargett, A. (2003), Differential diffusion: An oceanographic primer, Prog. Oceanogr., 56(3-4), 559-570.

Jackson, J. M., E. C. Carmack, F. A. McLaughlin, S. E. Allen, and R. G. Ingram (2010a), Identification, characterization and change of the near-surface temperature maximum in the Canada Basin, 1993-2008, J. Geophys. Res., 115, C05021, doi:10.1029/2009JC005265.

Jackson, J. M., S. E. Allen, E. C. Carmack, and F. A. McLaughlin (2010b), Suspended particles in the Canada Basin from optical and bottle data, 2003-08, Ocean Sci., 6, 799-813.

Jahn, A., B. Tremblay, L. A. Mysak, and R. Newton (2010), Effect of the large-scale atmospheric circulation on the variability of the Arctic Ocean freshwater transport, Clim. Dyn., 34(2-3), 201-222.

Krishfield, R., J. Toole, A. Proshutinsky, and M.-L. Timmermans (2008), Automated Ice-Tethered Profilers for seawater observations under pack ice in all seasons, J. Atmos. Oceanic Technol., 25(11), 2091-2105.

Li, W. K. W., F. A. McLaughlin, C. Lovejoy, and E. C. Carmack (2009), Smallest algae thrive as the Arctic Ocean freshens, Science, 326, 539.

Macdonald, R. W., M. O’Brien, E. C. Carmack, R. Pearson, F. A McLaughlin, D. Sieberg, J. Barwell-Clarke, D. W. Paton, and D. Tuele (1995), Physical and chemical data collected in the Beaufort, Chukchi and East Siberian Seas, August-September 1993, Can. Data Rep. Hydrogr. Ocean Sci. 139, 287 pp., Gov. of Can., Ottawa, Ont.

Maslanik, J., and J. Stroeve (1999), Near-Real-Time DMSP SSM/I-SSMIS Daily Polar Gridded Sea Ice Concentrations, http://nsidc.org/data/nsidc0081.html, Natl. Snow and Ice Data Cent., Boulder, Colo. [Updated daily.]

McLaughlin, F. A., and E. C. Carmack (2010), Deepening of the nutricline and chlorophyll maximum in the Canada Basin interior, 2003-2009, Geophys. Res. Lett., 37, L24602, doi:10.1029/2010GL045459.

McLaughlin, F. A., E. C. Carmack, R. W. Macdonald, H. Melling, J. H. Swift, P. A. Wheeler, B. F. Sherr, and E. B. Sherr (2004), The joint roles of Pacific and Atlantic-origin waters in the Canada Basin, 1997-1998, Deep Sea Res. Part I, 51, 107-128.

McLaughlin, F. A., E. C. Carmack, S. Zimmerman, D. Sieberg, L. White, J. Barwell-Clarke, M. Steel, and W. K. W. Li (2008), Physical and chemical data from the Canada Basin, August, 2004, Can. Data Rep. Hydrog. Ocean Sci. 140, 185 pp., Gov. of Can., Ottawa, Ont.

McPhee, M. G., A. Proshutinsky, J. H. Morison, M. Steele, and M. B. Alkire (2009), Rapid change in freshwater content of the Arctic Ocean, Geophys. Res. Lett., 36, L10602, doi:10.1029/2009GL037525.

Morison, J., and J. D. Smith (1981), Seasonal variations in the upper Arctic Ocean as observed at T-3, Geophys. Res. Lett., 8(7), 753-756.

Münchow, A., and E. C. Carmack (1997), Synoptic flow and density observations near and Arctic shelf break, J. Phys. Oceaongr., 27, 1402-1419.

Nikolopoulos, A., R. S. Pickart, P. S. Fratantoni, K. Shimada, D. J. Torres, and E. P. Jones (2009), The western Arctic boundary current at $152^{\circ} \mathrm{W}$ : Structure, variability and transport, Deep Sea Res. Part II, 56, 1164-1181.
Overland, J. E. (2009), Meteorology of the Beaufort Sea, J. Geophys. Res., 114, C00A07, doi:10.1029/2008JC004861.

Panteleev, G., D. A. Nechaev, A. Proshutinsky, R. Woodgate, and J. Zhang (2010), Reconstruction and analysis of the Chukchi Sea circulation in 1990-1991, J. Geophys. Res., 115, C08023, doi:10.1029/2009JC005453. Perovich, D. K., B. Light, H. Eicken, K. F. Jones, K. Runciman, and S. V. Nghiem (2007), Increasing solar heating of the Arctic Ocean and adjacent seas, 1979-2005: Attribution and role in the ice-albedo feedback, Geophys. Res. Lett., 34, L19505, doi:10.1029/2007GL031480.

Pickart, R. S. (2004), Shelfbreak circulation in the Alaskan Beaufort Sea: Mean structure and variability, J. Geophys. Res., 109, C04024, doi:10.1029/2003JC001912.

Pinkel, R. (2005), Near-inertial wave propagation in the western Arctic, J. Phys. Oceanogr., 35, 645-665.

Proshutinsky, A. Y., and M. Johnson (1997), Two circulation regimes of the wind driven Arctic Ocean, J. Geophys. Res., 102, 12,493-12,514.

Proshutinsky, A., R. H. Bourke, and F. A. McLaughlin (2002), The role of the Beaufort Gyre in Arctic climate variability: Seasonal to decadal climate scales, Geophys. Res. Lett., 29(23), 2100, doi:10.1029/2002GL015847.

Proshutinsky, A., R. Krishfield, M.-L. Timmermans, J. Toole, E. Carmack, F. McLaughlin, W. J. Williams, S. Zimmerman, M. Itoh, and K. Shimada (2009), Beaufort Gyre freshwater reservoir: State and variability from observations, J. Geophys. Res., 114, C00A10, doi:10.1029/2008JC005104.

Rainville, L., and R. A. Woodgate (2009), Observations of internal wave generation in the seasonally ice-free Arctic, Geophys. Res. Lett., 36, L23604, doi:10.1029/2009GL041291.

Rudels, B., L. G. Anderson, and E. P. Jones (1996), Formation and evolution of the surface mixed layer and halocline of the Arctic Ocean, J. Geophys. Res., 101(C4), 8807-8821.

Shimada, K., E. C. Carmack, K. Hatakeyama, and T. Takizawa (2001), Varieties of shallow temperature maximum waters in the western Canadian Basin of the Arctic Ocean, Geophys. Res. Lett., 28(18), 3441-3444.

Shimada, K., T. Kamoshida, M. Itoh, S. Nishino, E. Carmack, F. McLaughlin, S. Zimmerman, and A. Proshutinsky (2006), Pacific Ocean inflow: Influence on catastrophic reduction of sea ice cover in the Arctic Ocean, Geophys. Res. Lett., 33, L08605, doi:10.1029/2005GL025624.

Steele, M., J. Morison, W. Ermold, I. Rigor, M. Ortmeyer, and K. Shimada (2004), Circulation of summer Pacific halocline water in the Arctic Ocean, J. Geophys. Res., 109, C02027, doi:10.1029/2003JC002009.

Steele, M., J. Zhang, and W. Ermold (2010), Mechanisms of summertime upper Arctic Ocean warming and the effect on sea ice melt, J. Geophys. Res., 115, C11004, doi:10.1029/2009JC005849.

Timmermans, M.-L., J. Toole, A. Proshutinsky, R. Krishfield, and A. Plueddemann (2008), Eddies in the Canada Basin, Arctic Ocean, observed from Ice-Tethered Profilers, J. Phys. Oceanogr., 38, 133-145.

Toole, J., et al. (2006), Ice-Tethered Profilers sample the upper Arctic Ocean, EOS Trans. AGU, 87(41), 434,438

Toole, J. M., M.-L. Timmermans, D. K. Perovich, R. A. Krishfield, A. Proshutinsky, and J. A. Richter-Menge (2010), Influences of the ocean surface mixed layer and thermohaline stratification on Arctic Sea ice in the central Canada Basin, J. Geophys. Res., 115 C10018, doi:10.1029/2009JC005660.

United Nations Educational, Scientific and Cultural Organization (1981), Background papers and supporting data on the Practical Salinity Scale 1978, Unesco Tech. Pap. Mar. Sci. 37, 144 pp., Paris.

Watanabe, E., and H. Hasumi (2009), Pacific water transport in the western Arctic Ocean simulated by an eddy-resolving coupled sea ice-ocean model, J. Phys. Oceanogr., 39, 2194-2211.

Weingartner, T. J., D. J. Cavalieri, K. Aagaard, and Y. Sasaki (1998), Circulation, dense water formation, and outflow on the northeast Chukchi shelf, J. Geophys. Res., 103(C4), 7647-7661.

Woodgate, R. A., and K. Aagaard (2005), Revising the Bering Strait freshwater flux into the Arctic Ocean, Geophys. Res. Lett., 32, L02602, doi:10.1029/2004GL021747.

Woodgate, R. A., K. Aagaard, and T. J. Weingartner (2005a), Monthly temperature, salinity, and transport variability of the Bering Strait through flow, Geophys. Res. Lett., 32, L04601, doi:10.1029/2004GL021880.

Woodgate, R. A., K. Aagaard, and T. J. Weingartner (2005b), A year in the physical oceanography of the Chukchi Sea: Moored measurements from autumn 1990-1991, Deep Sea Res. Part II, 52, 3116-3149.

Woodgate, R. A., K. Aagaard, and T. J. Weingartner (2006), Interannual changes in the Bering Strait fluxes of volume, heat, and freshwater between 1991 and 2004, Geophys. Res. Lett., 33, L15609, doi:10.1029/ 2006GL026931.

Woodgate, R. A., T. Weingartner, and R. Lindsay (2010), The 2007 Bering Strait oceanic heat flux and anomalous Arctic sea-ice retreat, Geophys. Res. Lett., 37, L01602, doi:10.1029/2009GL041621.

Yamamoto-Kawai, M., F. A. McLaughlin, E. C. Carmack, S. Nishino, K. Shimada, and N. Kurita (2009), Surface freshening of the Canada 
Basin, 2003-2007: River runoff versus sea ice meltwater, J. Geophys. Res., 114, C00A05, doi:10.1029/2008JC005000.

S. E. Allen, Department of Earth and Ocean Sciences, University of British Columbia, 6339 Stores Rd., Vancouver, BC V6T 1Z4, Canada. (sallen@eos.ubc.ca)

E. C. Carmack and F. A. McLaughlin, Fisheries and Oceans Canada, Institute of Ocean Sciences, PO Box 6000, Sidney, BC V8L 4B2,
CANADA. (eddy.carmack@dfo-mpo.gc.ca; fiona.mclaughlin@dfo-mpo. gc.ca)

J. M. Jackson, Department of Oceanography, University of Cape Town, Private Bay X3, Rondebosch, Cape Town, Western Cape 7701, South Africa. (jennifer.jackson@uct.ac.za)

R. A. Woodgate, Applied Physics Laboratory, University of Washington, Box 355640, 1013 NE 40th St., Seattle, WA 98105-669, USA. (woodgate@apl.washington.edu) 